Data Analysis of the 1984 and 1986

Soil Sampling Programs

at Materials Disposal Area $T$

in the Los Alamos National Laboratory

John W. Nyhan

Barry J. Drennon 


\section{CONTENTS}

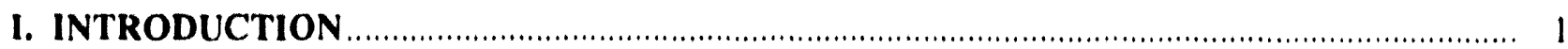

II. DISPOSAL, SITE DESCRIPTION AND WASTE USE HISTORY .................................. 2

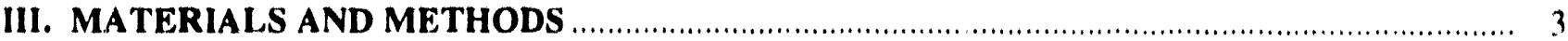

A. Soll Sampling, Surveying, and Radionuclide Assay Techniques ............................................ $\quad 3$

B. Conversions to New Mexico State Plane Coordinate System ................................................ 5

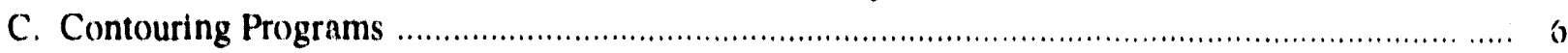

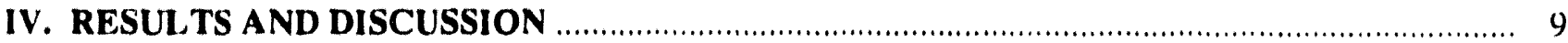

A. Survey results for waste site physical features and soll sampling grids ................................... 9

B. Survey results for soil radionuclide concentrations ......................................................... 20

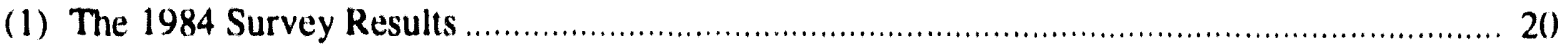

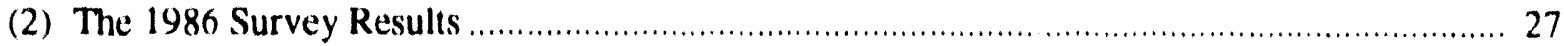

V. USEFULNESS OF DATA ANAL, YSIS

AND RECOMMENDATIONS FOR FUTURE STUDIES _........................................... 32

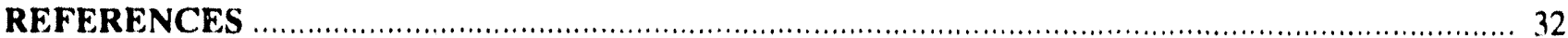




\title{
DATA ANALYSIS OF THE \\ 1984 AND 1986 SOIL SAMPLING PKOGRAMS \\ AT MATERIALS DISPOSAL AREA T IN THE \\ I.OS ALAMOS NATIONAL LABORATORY
}

by

John W. Nyhan and Barry J. Drennon

\begin{abstract}
An environmental surveillance program for Materials Disposal Area T (MDA-T) at Los Alamos, New Mexico is described. The waste-use history of this disposal site is described, followed by a description of the materials and methods used to analyze data from iwo surface soil radionuclide sampling programs performed at this disposal site. The disposal site's physical features are related to the spatial distribution of radionuclide concentration contours in an attempt to evaluate radionuclide migration mechanisms in and around the site. The usefulness of the data analysis efforts is evaluated and recommendations are made for future studies.
\end{abstract}

\section{INTRODUCTION}

In the late 1970s the Department of Energy (DOE) issued interim operational criteria for radioactive waste areas owned or operated by DOE and its contractors ( $1-3)$. As a tirst response to the surveillance requirements listed in these criteria, personnel from the Environmental Surveillance Group at the Los Alamos Scientific Laboratory (LASL) developed an interim surveillance plan for the site's radioactive waste areas (4). More specifically, the stated objectives of this plan were to:

"(1) provide information to evaluate whether radioactive waste sites at LASL are being managed and maintained in an environmentally acceptable manner; and whether applicable criteria, such as the DOE Interim Criteria for Waste Management are met;

(2) identify and document possible changes over time for each area;

(3) provide data for the Annual Environmental Surveillance Report; and
(4) provide other envirommental documentation that might be required prior (1) changes or additions 10 activities at L.ASL."

The original plan (4) called for a brief annual survey of each waste site starting at the end of FY - 1981, involving portable radiation detector surveys and sampling programs for soils, vegetation, air, and smuil niammals. All additional detailed survey was to be performed on each waste area at least once every five years, with (wo or three waste areas being subject (1) this type of survey within any given year. The detailed surveys were meant 10 encompass more sampling locations, techniques with lower delection limits, and extensive sampling of surtace soils (three depths in the 10 p $30 \mathrm{~cm}$ of soil) and subsurface soils (depths below $30 \mathrm{~cm}$ ).

Concurrent with the initial annual survey at each waste disposal area, a sampling grid was to be established by civil engineering surveys (4). The grid origin was to be randomly chosen to mitigate against bias in placement of grid points across the grid. Key points, coordinate axes 
and perimeters were 10 be installed to assure adequate accuracy. An emphasis was placed on relating the sampling grids to the local Los Alamos Scientific Laboratory coordinate system.

A recent summary of this routine monitoring and special study research data at MDA-T was published (5), which described data collected from 1946 through 1986 (see Appendix A-3). This summary suggests that only two detailed surface soil surveys of this disposal site had the potential of yielding useful information for documenting site surveillance activities for the current DOE Environmental Restoration Program activities. These two surveys were both performed as part of the original DOE program described earlier (4). Soil samples for these two surveys were collected in June 1984 and from June through July 1986. Although the results of the 1984 survey were never summarized in a report, the 1986 survey is well documented (5).

The objectives of this study were (1) to document the sampling locations, sampling methods, and analytical methods used in the 1984 and 1986 surveys at MDA-T and (2) to perform data analysis on the results of the radionuclide assays performed on the soil samples collected. The results of this documentation and data analysis will be used to design a soil sampling prograun at this disposal as part of the activities of the Environmental Restoration program.

\section{DISPOSAL SITE DESCRIPTION AND WASTE USE HISTORY}

MDA-T is within Technical Area 21 of the Los Alamos National Laboratory (Fig. 1) and can be reached from the north perimeter road. This disposal site is less than a quarter mile from the intersection of the north perimeter road and DP Road (6). Most of the area is found within LASL coordinates $\mathrm{N} .87+50$ and $\mathrm{N} .90+00$, and E. $157+50$ and $\mathrm{E} .160+00$, with an approximate total acreage of 0.88 . MDA-T is physically located east of Buildings TA-21-286 and TA-21-288 and west of Building TA-21-257.

Three different disposal modes were used at MDA-T (6). The absorption beds are the oldest used for the disposal of liquid wastes at Los Alamos (Fig. 2) and have been described in detail (6). After the construction of the 1.2-m deep, $36.6-\mathrm{m}$ by $6.1-\mathrm{m}$ absorption beds was completed in 1945, they received untreated radioactive liquid wastes from 1945 through 1951 from DP Site. The DP West liquid waste treatment plant was installed in
1952, largely because the volume of liquids discharged to the beds exceeded the holding capacity of the absorption beds, despite the fact that the beds were equipped with a distribution box, located between beds 1 and 2, which ensured that approximately equal volumes of wastes were discharged to these two beds. About $89 \%$ of the $69260 \mathrm{~m}^{3}$ of liquid effluents added to the MDA-T absorption beds were added between 1945 and 1960 , with the remaining $11 \%$ added in rapidly decreasing amounts until 1967. A new treatment plant was built in 1967, which also infrequently discharged treated wastes into the absorption beds. However, almost all of these treated effluents were discharged to the canyon north of the plant.

Both the addition rate and the type of waste added to the absorption beds changed with time at MDA-T. About 98\% of the estimated $10 \mathrm{Ci}$ of Pu discharged to the absorption beds was added as untreated wastes between 1945 and $1952(6,7)$. The concentration of $\mathrm{Pu}$ in the estimated $53000 \mathrm{~m}^{3}$ of untreated effluents during this period was estimated at about $27 \mathrm{pCi} \mathrm{Pu/ml}$, with an average fluoride concentration associated with the wastes of $160 \mathrm{ppm}$. However, about $40 \mathrm{~m}^{3}$ of untreated effluents containing large concentrations of ammonium citrate were released into the beds from June 1951 to July 1952 , and these wastes contained about 6300 p(i Pu/ml and $200 \mathrm{ppm}$ fluoride. The smallest contributions to the beds came between 1953 and 1967 when about $16000 \mathrm{~m}^{6}$ of treated effluents containing only about $0.09 \mathrm{pCi} \mathrm{Pu} / \mathrm{ml}$ were discharged to the absorption beds. As of January 1973, the absorption beds contained $4 \mathrm{Ci}$ of tritium and about $10 \mathrm{Ci}$ of ${ }^{239} \mathrm{Pu}$, generally consisting of approximately $94 \%{ }^{239} \mathrm{Pu}$ and $6 \%{ }^{24(1} \mathrm{Pu}$ hy weight

Forty-nine 8 -ft diameter disposal shatts (on $12-\mathrm{ft}$ centers) and thirteen 6-ft diameter disposal shafts were augered with a bucket auger, principally between Absorption Beds 2 and 4 (Figures 3 and 4). These shalts were augered to depths of 15 to 68 ft hetween 1970) and 1976 (6). The wastes going to the shafts, which were lined with asphalt, were mixed with cement and pumped down the shafts. As of July 1976, these 62 disposal shatts contained approximately $47 \mathrm{Ci}$ of ${ }^{238} \mathrm{Pu}, 191 \mathrm{Ci}$ of ${ }^{239} \mathrm{Pu}$, $3761 \mathrm{Ci}$ of ${ }^{241} \mathrm{Am}, 7 \mathrm{Ci}$ of ${ }^{233} \mathrm{U}$, and 3 ( $\mathrm{i}$ of mixed fission products (6).

The third disposal mode al MDA-T consisted of waste disposal in 20 ft-long corrugated melal pipes (CMPs) with a diameter of 30 inches within the Retrievable Waste Storage Area (primarily located between Absorption Beds 1 and 3; see Figures 5 and 6). Treated wastes from TA-21.257 were inixed with cement and pumped into the 


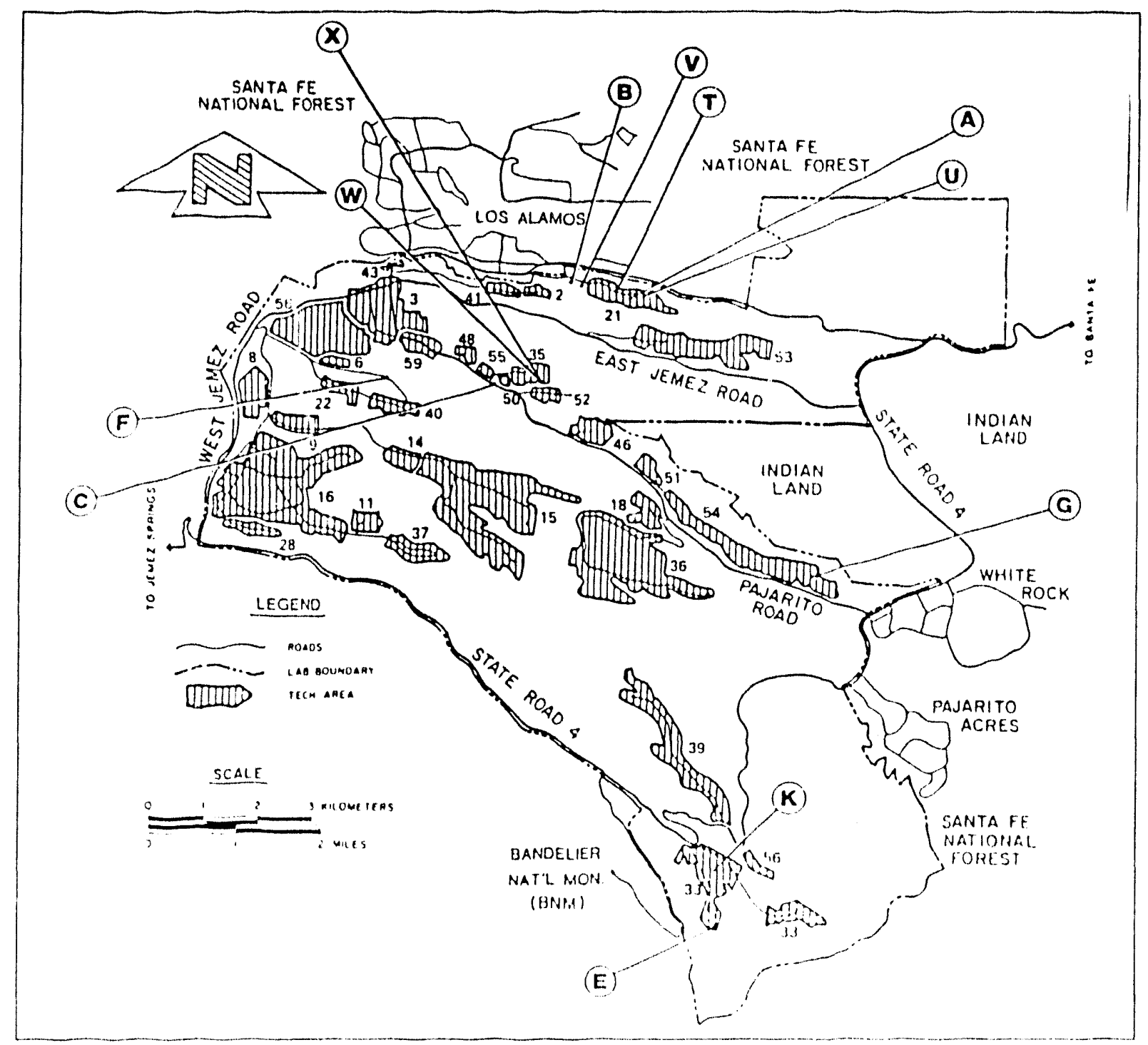

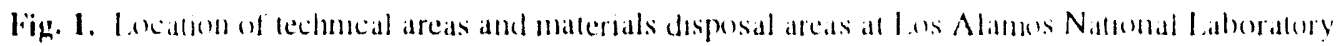

('MPs. Sixly-ninc of llose ( MP's contained low-level radionctive wasles will a lotal inventory $(8)$ of $0.77 \mathrm{Ci}$ (1).(144 g) ${ }^{238} \mathrm{Pu}, 1.18$ ( $\mathrm{i}(19.2 \mathrm{~g})^{239} \mathrm{Pu}, 15.3(\mathrm{i}(4.7 \mathrm{~g})$ ${ }^{241} \mathrm{Am}$, and 0.16 ( $\mathrm{i}$ of mixed fission products. All 69) (MPs were relocaled io MDA-G in 1984. An additional 158 CMPs contained transuranic wastes with a lotal inventory $(8)$ of $30.97 \mathrm{Ci}(1.8 \mathrm{~g}){ }^{238} \mathrm{Pu}, 59.4 \mathrm{Ci}$ $(966.9 \mathrm{~g})^{239} \mathrm{Pu}, 1038.5 .4\left(\mathrm{i}(3205.4 \mathrm{~g}){ }^{241} \mathrm{Am}\right.$, and $0.4(\mathrm{i}$ of mixed fission products. These 158 CMPs were relocated to MDA.G in 1986

\section{MATLKIAIS ANI) MIFI'I(U)S}

\section{A. Soil Sampling, Surveying, and Radionuclide Assay Technicues}

Soil sampling techniques were initially outlined in the interim environmental surveillance plan for this ongoing DOE program (4). The delails of how the samples were actually collected and processed for radiochemical analysis were never fully documented. This information will be presented here as the result of interviewing 


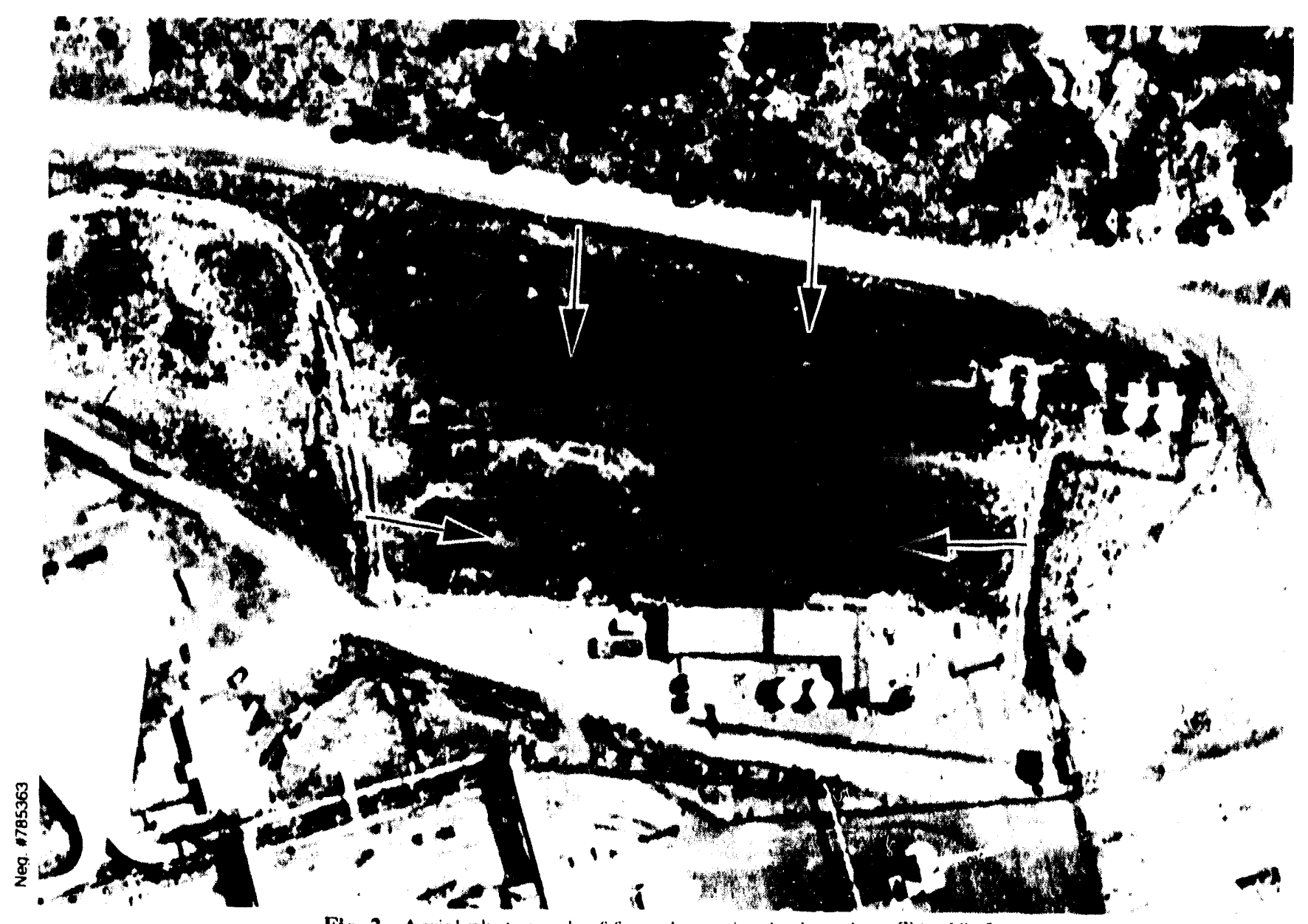

Fig. 2. Aerial photograph of four absorption beds at Area T in 1965

personnel of the Environmental Surveillance Group who actually collected the samples since the initiation of this program in 1979.

Through 1985, approximately 500 to $900 \mathrm{~g}$ of soil were sampled from each of the $0.1,1-10 \mathrm{~cm}$, and $10.30 \mathrm{~cm}$ layers of the soil profilc at each sampling location. The original concept was to attempt to collect samples of approximately the same weight from each sampling depth. Thus, a steel cylinder (9) with an inside diameter of $30 \mathrm{~cm}$ and a height of $1 \mathrm{~cm}$ was used in collecting samplings from the $0-1 \mathrm{~cm}$ depth. After this sample was removed, a steel cylinder (9) with an inside diameter of $7.5 \mathrm{~cm}$ and a height of $9 \mathrm{~cm}$ was placed in the center of the previous excavation and driven into the profile to collect the $1-10 \mathrm{~cm}$ sample. The final $10-30 \mathrm{~cm}$ sample was collected in the same hole by driving a metal scoop with an inside diameter of $7.5 \mathrm{~cm}$ to the final $30 \mathrm{~cm}$ depth.In 1986, surface soil samples were collected to a depth of
$5 \mathrm{~cm}$ using a coring too! with a $7.5 \mathrm{~cm}$ inside diameter (5) Unlike all of the samples collected before 1986 (where the entire soil sample was analyzed), these samples were sieved through a 50 micron me a screen and only the fine fraction was analyzed for radionuclides.

The sampling locations were surveyed using different grid systems with time, as will be discussed in more detail later in this report. The intensive surveys performed through 1985 were based on the 1980) survey of MDA-A. This survey established sampling locations on $20 \mathrm{~m}$ centers for an area located as far west as MDA.T and as far east as MDA-U. The origin of this coordinate system was located near the southwestern gate (O) MDA-A. This origin was found to have New Mexico State Plane (NMSP) coordinates (feet) of 492997.24, 1774123.06 (10). The $Y$-axis of this coordinate system consisted of a N.60 $\left.60^{\circ} 2\right)^{\prime} 33^{\prime \prime} \mathrm{E}$. line which formed a $42^{\circ}$ angle with the easting lines of the LASL. coordinate system. Sampling 


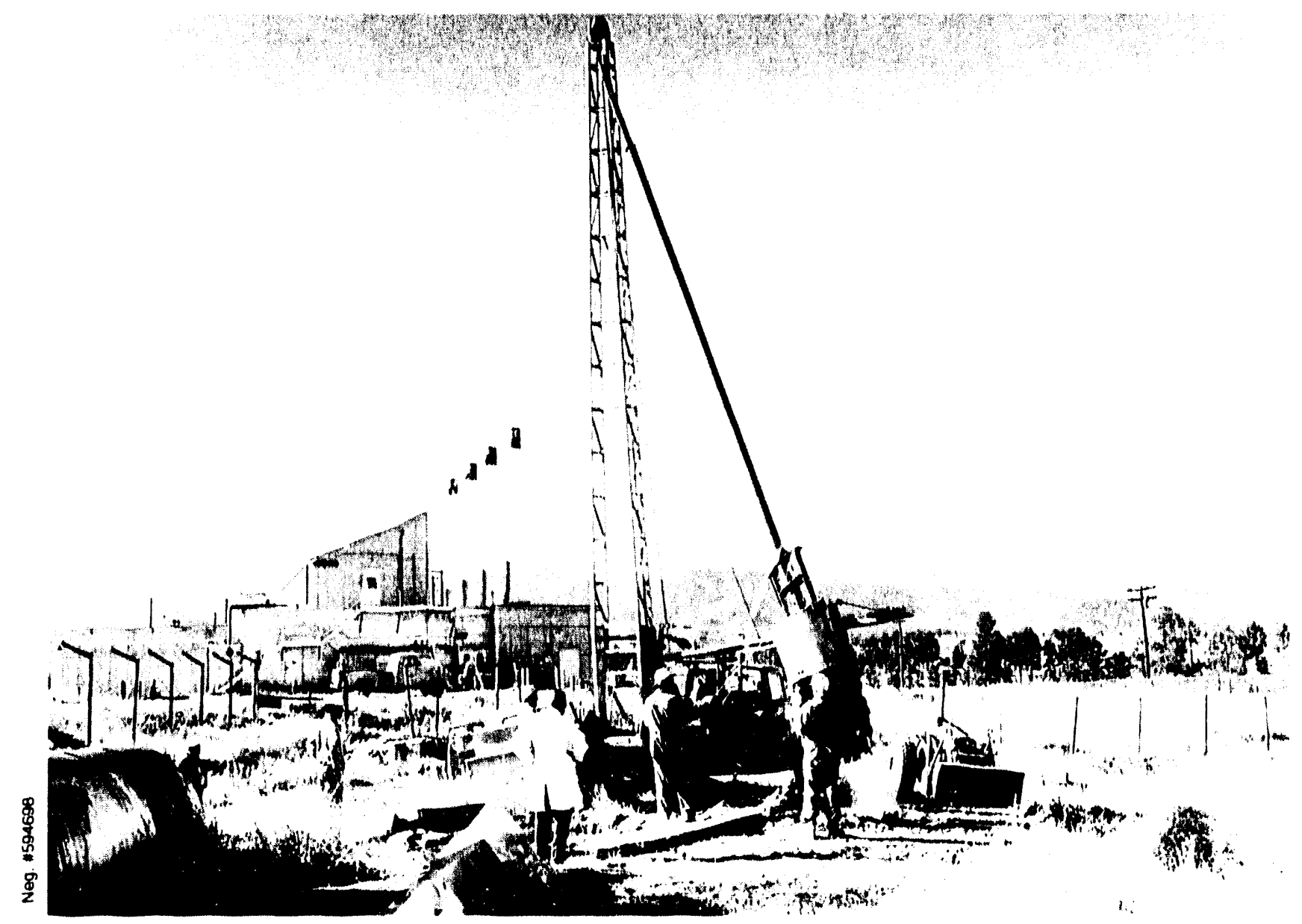

Fig. 3. Bucket auger heing used to drill disposal shafts between Absoption Beds 2 and 4 at MDA.T. Absorptun Beds 1 and 3 are behind the drill rig and represent the low areas lo each side of the drill rig.

locations were marked with flagged spikes flush with the ground surface by the Laboratory's surveyors (10).

In 1986 Environmental Science (iroup persomel laid out a grid of sampling locations across MDA-T on $10 \mathrm{~m}$ centers (5). This coordinate system was laid out with respect to two reference points, which were surveyed in February 1990 (Engineering Drawing ENG-21-61, February 15, 1990). The two reference points were: (1) a point near the northwest corner of Building DP-257, and (2) a point near a sewer manhole, identified in Engineering Drawing ENG-21-61 as sample points CA-1 and CA-2, respectively. More details about this grid system will be presented in the Results and Discussion section of this report.

The radiochemical procedures for processing the soil samples through 1985 are summarized in Los Alamos National Laboratory report LA-8810-EN(i (11). The analogous procedures for the assays on the 1986 samples are described in Los Alamos National Laboratory report LA-10992-ENV (12). Plutonium is chemically isolated from a 10-g aliquor of soil, electrodeposited and counted on an alpha spectometer. Notice that the ${ }^{2.39} \mathrm{Pu}$ values mentioned in this report actually represent the sum of ${ }^{239} \mathrm{P}_{\mathrm{u}}$ and ${ }^{24(1)} \mathrm{Pu}$, because both have identical alpha energies.

\section{B. Conversions to New Mexico State Plane Coordinate System}

Microcomputer programs were developed to convert all field location values to one common rectangular grid system, the NMSP coordinate system.

One progran allowed us Io take I. ASl. coordinates and adjacent brass cap dald to calculate NMSP coordinates. This program was used (o) calculate the NMSP coordinates for the absorption beds and disposal shatts at 


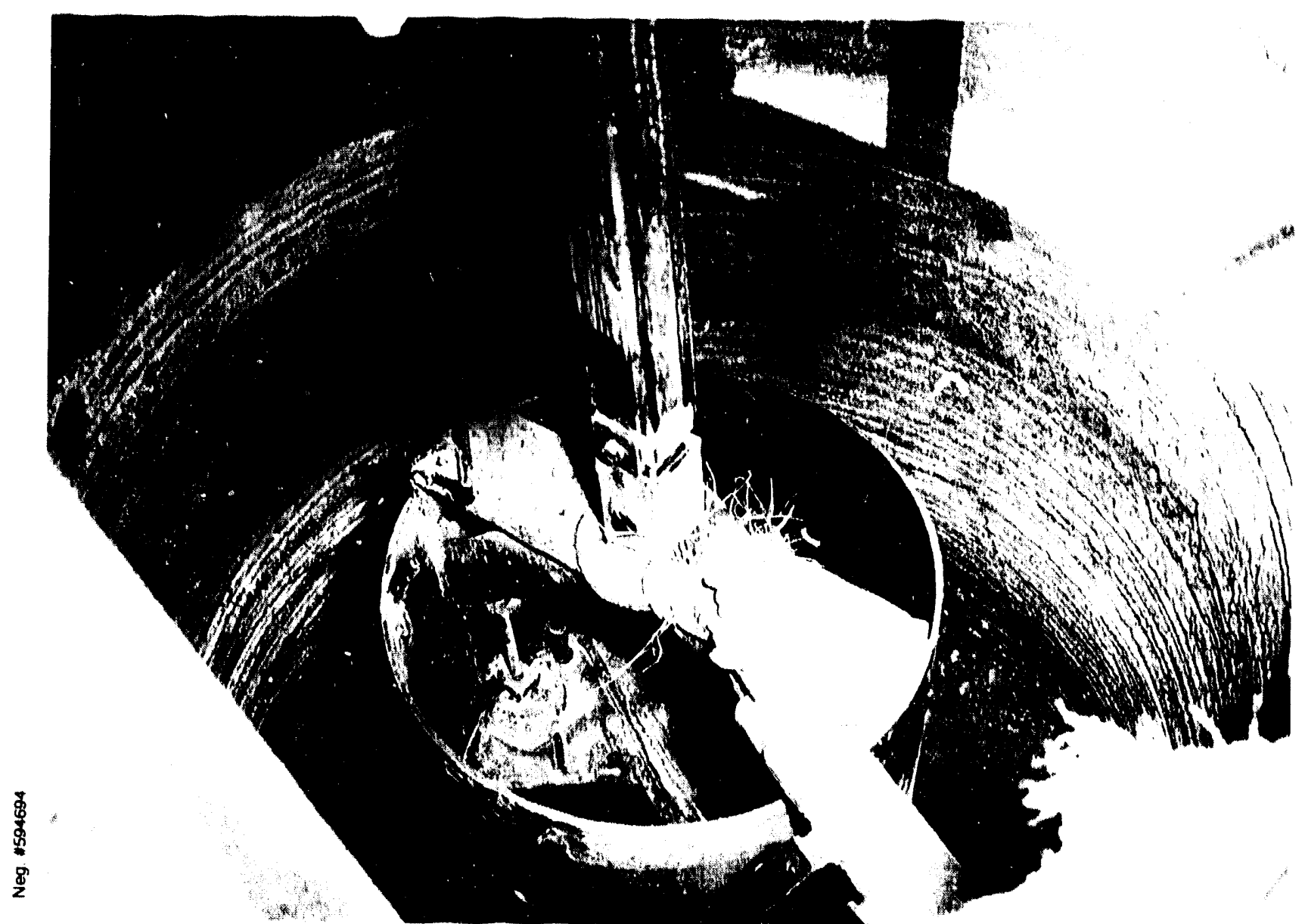

Fig. 4. Bucket auger (4-foot diameter) being used to ream a disposal shaft to a larger diameter at MDA-T.

MDA-T, using data for brass caps 503 and 753. The LASL coordinates for the four adsorption beds are given in Engineering Drawing ENG-C.2217 (June 13, 1945). The LASL coordinates for the disposal shafts were also estimated from this drawing.

\section{Contouring Programs}

Two programs were developed for use on a VAX 10 contour elevation and radionuclide concentration data tor MDA-T.

The first program was developed using Version 11 of CA-DISSPLAY 10 use (wo-foot elevation data from the MOSS GIS system maintained by the Laboratory's Engineering Division. This program produces elevation contours across MDA-T from a data base of over 360$)(0$ observations of NMSP eastings and northings, with associated elevation values.

The second program produces contours of radionuclide concentrations in surface soils in seven different concentration intervals. A map of these seven contours is produced using Version 11 of CA-DISSPLAY with the soil radionuclide data from each sampling grid location as the input. This progran takes the 600 by 6()) 11 field area encompassing MDA- $T$ and creates a matrix across this area in an illempt 10 generate regularly. spaced data values from a small number of data points. This matrix was either 16 by 16 regularly-spaced intervals for the 1984 soil data base (with 31 sampling locations) or 26 by 26 regularly-spaced intervals for the 1986 soil data base (with 71 sampling locations). The final surface of radionuclide contours ( $z$ values) was defined using a CA-DISSPLAY algorithm named MDFMAT. This function was used to search a total of three cells in the $x$ (easting values) direction and three cells in the $Y$ (northing values) direction with a weighting factor of 2.); this calculation was performed for each point on the original matrix. 


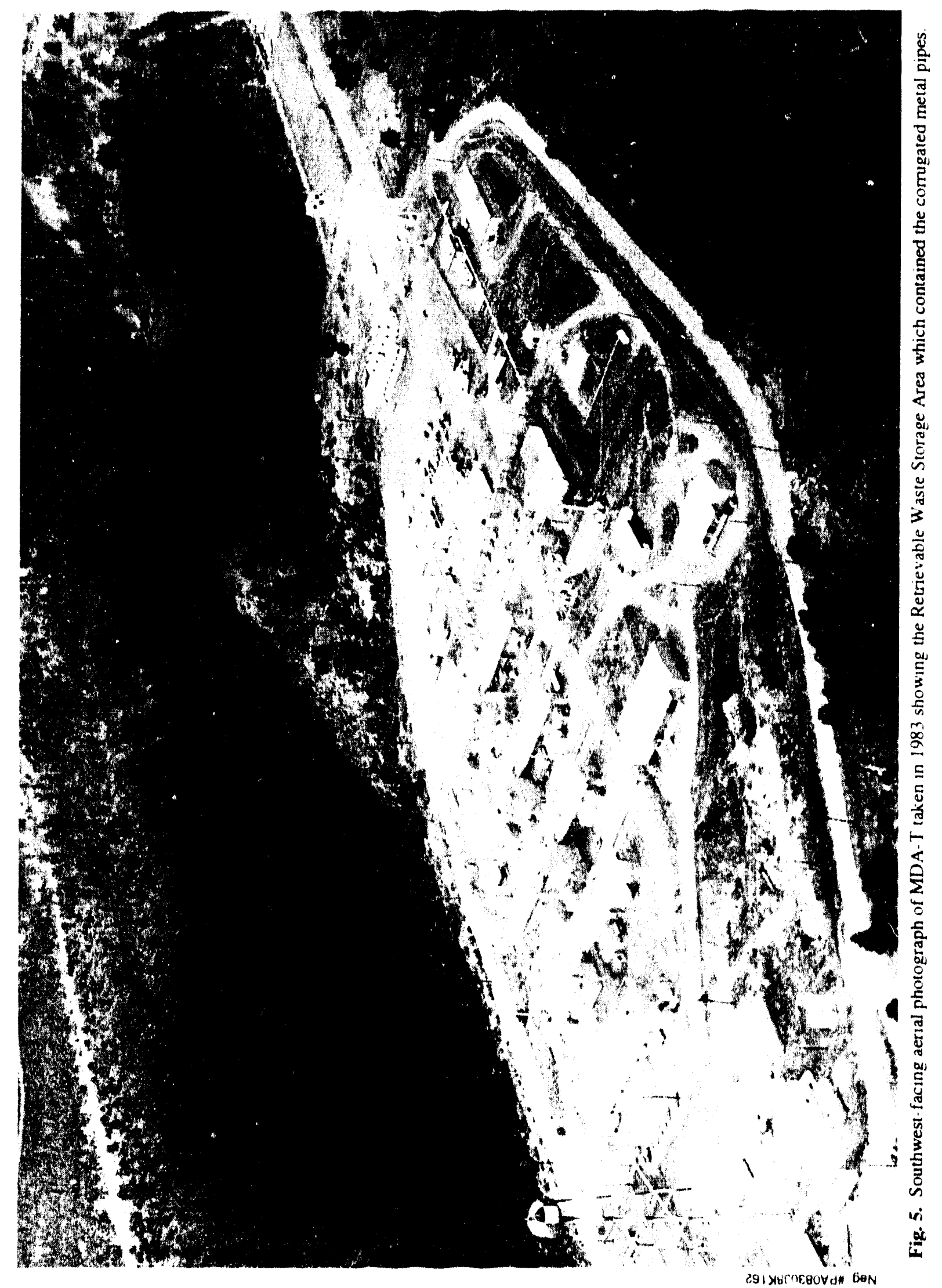




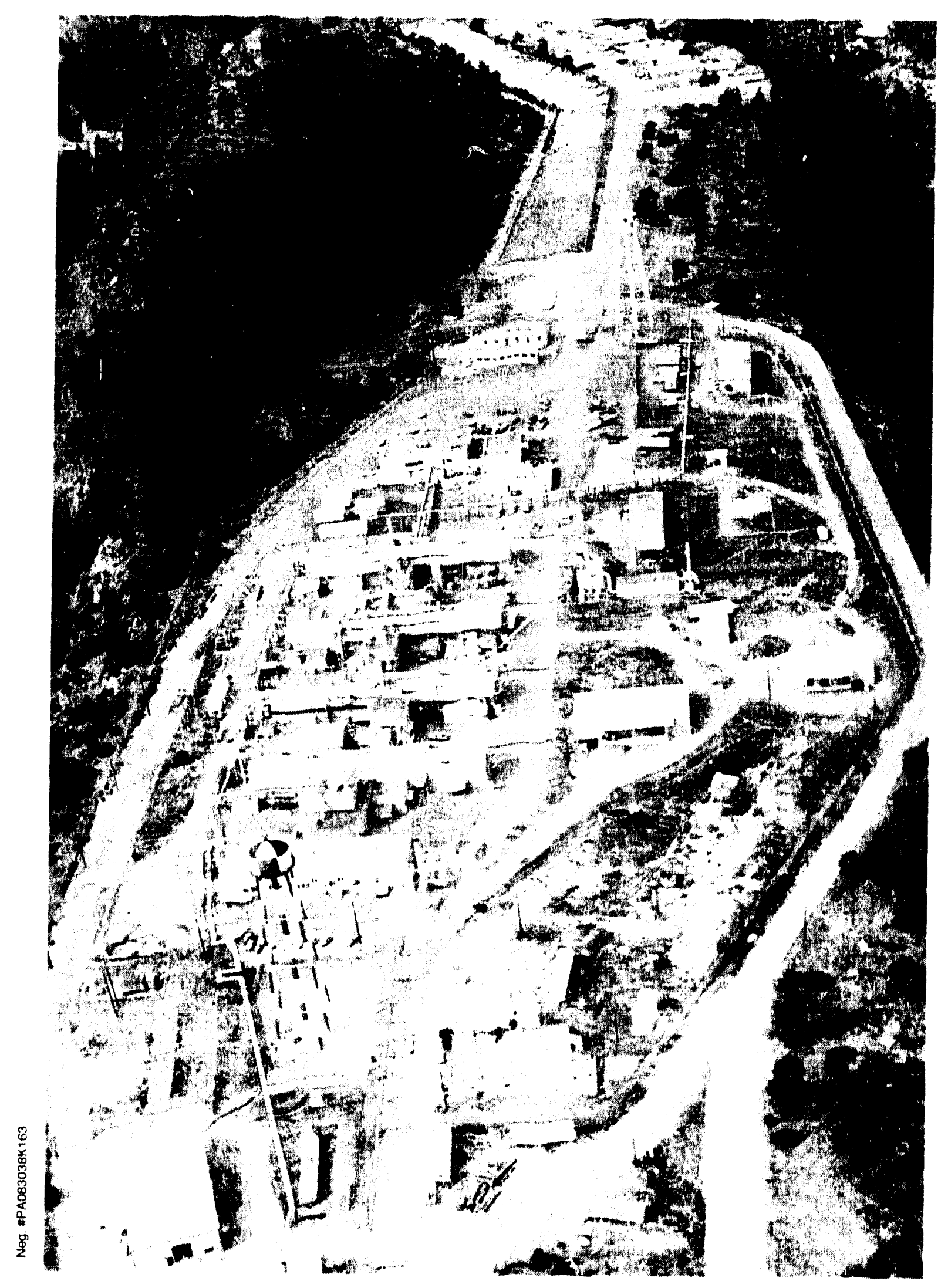

Fig. 6. West-facing acrial pholograph of MDA-T taken in 1983 showing the Retrievable Waste Storage Area which contained the corrugated metal pipes. 


\section{RESULTS AND DISCUSSION}

The locations of important waste site physical features (such as fence lines, absorption beds and disposal shafts) and sampling grids will be presented first in this section. because this data was needed hefore an analysis of the soil radionuclide data could he accomplished. The final subsection includes an analysis of the soil radionuclide data using a series of concentration contour plots

\section{A. Survey results for waste site physical features and soll sampling grids}

Using the two compuler programs described previously, NMSP coordinates were calculated for the four absorption beds at MDA-T ('Table 1), as well as for the (wo lypes of disposal shafts (Table 2). This dilta is presented in Figure 7, which also shows the old runvily 10 the area excupied hy the CMPs, as well as the tence around the disposal area

Table 1. Survey information for absorption heds at MDA-T.

\begin{tabular}{|c|c|c|c|}
\hline \multirow[b]{2}{*}{$\begin{array}{l}\text { Absorption } \\
\text { Bed Number }\end{array}$} & \multirow[b]{2}{*}{$\begin{array}{l}\text { Corner } \\
\text { of Bed }\end{array}$} & \multicolumn{2}{|c|}{ Northing/Easting Values* } \\
\hline & & $\begin{array}{l}\text { 1.ASL Grid } \\
\text { System }\end{array}$ & $\begin{array}{l}\text { New Mexicu State } \\
\text { Plane System }\end{array}$ \\
\hline \multirow[t]{8}{*}{1} & NW & $89+31.25$ & 1774510.94 \\
\hline & & $1.57+48.44$ & 4192368.34 \\
\hline & sW & $89+14.38$ & 1774494.57 \\
\hline & & $1.57+37.50$ & 4923.56 .67 \\
\hline & NE: & $88+52.81$ & 1774427.45 \\
\hline & & $1.58+6.5 .0()$ & 492481.34 \\
\hline & $\mathrm{SE}$ & $88+36.25$ & 1774411.38 \\
\hline & & $1.58+54.16$ & 492469.68 \\
\hline \multirow[t]{8}{*}{2} & NW & $88+47.50)$ & 1774421.84 \\
\hline & & $158+7191$ & $492488 .(1)$ \\
\hline & sW & $88+3(0.94$ & $17744(1.5 .78$ \\
\hline & & $1.58+60.97$ & 492476.35 \\
\hline & NE: & $87+6.5 .63$ & 1774334.66 \\
\hline & & $1.59+(1) 4.38$ & 492606.76 \\
\hline & Sl: & $87+48.75$ & 1774318.28 \\
\hline & & $1.59+83.44$ & 492595.188 \\
\hline \multirow{8}{*}{3} & NW & $89+97.50$ & 1774575.15 \\
\hline & & $157+93.44$ & 492416.21 \\
\hline & SW & $89+60.63$ & 1774538.79 \\
\hline & & $1.57+82.5()$ & 492403.66 \\
\hline & $\mathrm{NE}$ & $899+37.5()$ & 1774510.98 \\
\hline & & $1.58+8938$ & $4925(0) 42$ \\
\hline & SE & $89+(x) .94$ & 1774474.94 \\
\hline & & $158+78.44$ & 492496.88 \\
\hline \multirow[t]{8}{*}{4} & NW & $89+13.13$ & 177448.5 .37 \\
\hline & & $159+18.16$ & 492537.10 \\
\hline & $S W$ & $88+96.25$ & 177446990 \\
\hline & & $1.58+86.59$ & $4925(14.82$ \\
\hline & NE: & $88+25.63$ & 1774392.25 \\
\hline & & $16(0)+47.81$ & 492662.77 \\
\hline & $\mathrm{SE}$ & $88+(08.75$ & 177437.5 .88 \\
\hline & & 16()$+36.56$ & $4926.5(0.79$ \\
\hline
\end{tabular}


Table 2. Survey information for disposal shafts at MDA-T (estinuted from Engineerinf Drawing ENG.C.2217 and data frum Brass Caps 5(13) and 753).

\begin{tabular}{|c|c|}
\hline $\begin{array}{l}\text { Disposal Shaft } \\
\text { Number } \\
\end{array}$ & $\begin{array}{l}\text { New Mexico State Plane Survey Data } \\
\text { (Easting, Northing) }\end{array}$ \\
\hline \multicolumn{2}{|c|}{ 8-fl diam Disposal Shatls } \\
\hline 1 & $492642.30,1774367.50$ \\
\hline 2 & $4926.35 .30,1774357.80$ \\
\hline 3 & $492627.99,1774.48 .11$ \\
\hline 5 & $492611.12,1774345.73$ \\
\hline 6 & 492618.30 .17743555 .42 \\
\hline 8 & $4926.32 .61,1774.374 .81$ \\
\hline 9 & $492622.89,17744381.50$ \\
\hline 10 & 492615.91 .1774 .372 .10 \\
\hline 11 & $492608.61,1774.362 .73$ \\
\hline 13 & $492591.74,1774360.35$ \\
\hline 17 & $4926(0,3.52,1774.396 .11$ \\
\hline 18 & 492.596 .52 .1774386 .41 \\
\hline 19 & 492589.21 .1774376 .72 \\
\hline 20 & $492582.03,1774367.03$ \\
\hline $2 !$ & $492572,34,1774.374 .33$ \\
\hline 22 & $492579.52,1774.384 .0 .3$ \\
\hline 23 & $492586.84,1774.393 .71$ \\
\hline 24 & $492593,83,17744(1) 3,42$ \\
\hline 25 & 492584.13 .1774410 .41 \\
\hline 26 & $492577,13,17744(x) .71$ \\
\hline 27 & $492569.82,1774391.112$ \\
\hline 28 & 4) $25612,64,1774381,33$ \\
\hline 29 & $192552.95,1774388.64$ \\
\hline 30 & $492560,13,17743948,33$ \\
\hline 31 & $492567.45,1774408 .(1) 2$ \\
\hline 32 & $492.574,44,1774417.72$ \\
\hline 33 & $492.564 .74,1774424.72$ \\
\hline 34 & $492557.74,1774415.01$ \\
\hline 35 & $492550.43,1774405.33$ \\
\hline 36 & $492543.25,1774395.63$ \\
\hline 41 & $492545,35,1774439 .(12$ \\
\hline 42 & $492538,35,1774429,32$ \\
\hline 43 & $492531 .(14,1774419.63$ \\
\hline 44 & $492523.86,17744(09,94$ \\
\hline 46 & $492521.35,1774426.94$ \\
\hline 47 & 492528.67 .17744 .36 .62 \\
\hline 48 & $492535.66,17744466,33$ \\
\hline 49 & $492525.96,1774453.3 .3$ \\
\hline 50 & $492518.97,177444,3.63$ \\
\hline 51 & $492511,65,17744,33.94$ \\
\hline 52 & $492501,94,1774440.62$ \\
\hline 53 & $492509.25,1774450,31$ \\
\hline 54 & $492516.24,1774460.01$ \\
\hline 55 & $4925160,56,1774467.32$ \\
\hline 56 & $4(24) 9.56,1774457.61$ \\
\hline 57 & $492492.25,1774447.93$ \\
\hline 58 & $492482.56,17744.55 .24$ \\
\hline 59 & $492489.87 .17744(44.93$ \\
\hline 60 & $492496.87,1774474.63$ \\
\hline
\end{tabular}


Table 2. Survey information for disposal shafts at MDA-T (estimated from Engineering Drawing ENG-C-2217 and data from Brass Caps 503 and 753). (Cont.)

\begin{tabular}{cc}
$\begin{array}{c}\text { Disposal Shaft } \\
\text { Number }\end{array}$ & $\begin{array}{c}\text { New Mexico State Plane Survey Data } \\
\text { (Easting, Northing) }\end{array}$ \\
\hline 6-fldiam Disposal Shafts & \\
70 & $492590.85,1774367.89$ \\
75 & $4925.81 .16,1774375.20$ \\
76 & $492571.46,1774382.19$ \\
78 & $492585.93,1774401.57$ \\
80 & $492569.24,1774399.18$ \\
82 & $492552.07,1774396.50$ \\
83 & $492559.54,1774406.18$ \\
84 & $492566.54,1774415.88$ \\
87 & $492542.37,1774403.49$ \\
91 & $492537.45,1774437.18$ \\
92 & $492530.45,1774427.48$ \\
44 & $492520.76,1774434.79$ \\
95 & $492527.76,1774444.49$ \\
98 & $492501.37,1774449.06$ \\
\hline
\end{tabular}

The calculated NMSP coordinates for the 1984 survey of MDA-T are presented in Table 3. The unpublished original sample grid coordinates are presented for each soil sample collected at each sample location. The sample identification number assigned to each soil sample which underwent radionuclide analysis by the Laboratory's Health and Environmental Chemistry Group is listed in the last column in this table.

The original two reference points for the 1986 sampling grid were surveyed in 1990 (see discussion in Materials and Methods section) and an origin for the grid was derived, all in NMSP units (Table 4). The sampling grid was reconstructed from these original reference points (Fig. 8), but it incorrectly portrayed where the samples were actually collected (5). We discovered that both the origin and the other two reference points had to be adjusted as shown in Table 4 to get the sample grid locations to appear in their correct positions (5), as shown in Figure 9. Based on these adjusted NMSP coordinates for each sampling location, we then were able to reconstruct information for the 1986 survey (Table 5). All further references to the 1986 survey in this report will use the NMSP coordinates listed in Table 5 and shown in Figure 9.
Two-foot elevation contours data were collected from a 1986 elevation survey of the Laboratory, accessed through the Laboratory's Engineering Division (MOSS system). This elevation information is presented in conjunction with the 30 sampling locations in the 1984 survey (Fig. 10) and with the 71 sampling locations in the 1986 survey (Fig. 11). These (wo) figures show that the southeastern portion of MDA-T has an elevation of about $7144 \mathrm{ft}$, proceeding to an elevation of $7130 \mathrm{ft}$ close to the northwestern fence boundary. It is important to notice that the sample locations for both surveys were all collected above an elevation of about $7100 \mathrm{ft}$. As both Figures 10 and 11 show, the severe drop-off into DP Canyon starts at about $7100 \mathrm{ft}$ to an elevation of about $7060 \mathrm{ft}$ to the northwest. Elevations of about $7050 \mathrm{ft}$ and lower are more typical of the regional bottom of this major canyon system.

Two other major elevation features should be noticed (Figs. 10 and 11). A large mound of excavated cuff was placed over the southern absorption beds, just south of the $7140 \mathrm{ft}$ contour line, and extended to a total elevation of about $7160 \mathrm{ft}$. This tuff was excavated from the CMP runway area (see Figs. 5 and 6 ), which exhibited a major depression between absorption beds 1 and 3 to a minimum elevation of about $7122 \mathrm{ft}$. 


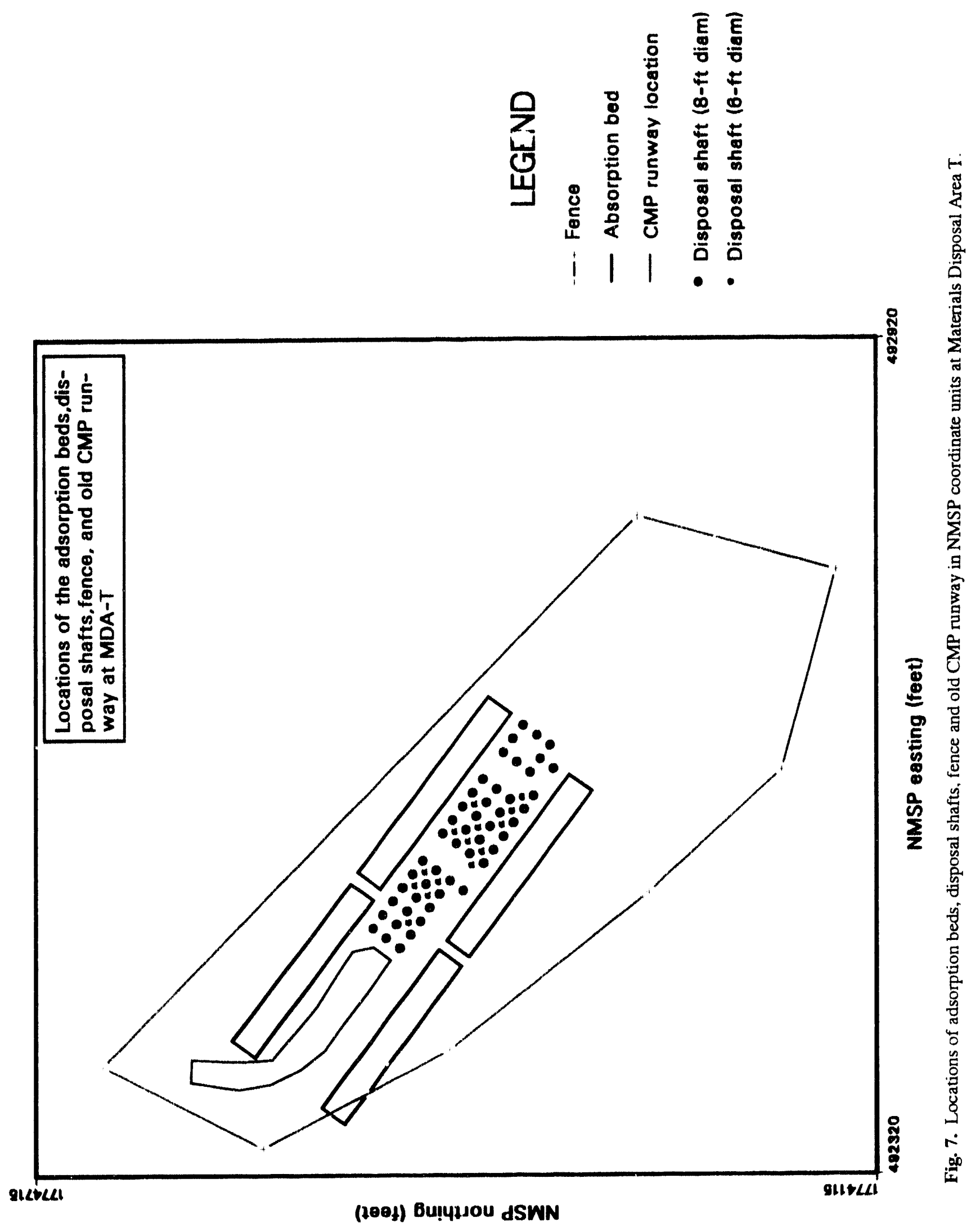


Table 3. Sampling grid coordinates, New Mexico State Plane coordinates and radionuclide sample numbers for the 1984 survey of MDA.T.

\begin{tabular}{|c|c|c|c|c|}
\hline \multicolumn{2}{|c|}{ Sample Grid System } & \multicolumn{2}{|c|}{ NMSP System } & \multirow{2}{*}{$\begin{array}{l}\text { Sample } \\
\text { Number }\end{array}$} \\
\hline Easting & Northing & Easting & Northing & \\
\hline-60.00 & -20.00 & 492843.18 & 1774262.06 & 84.04146 \\
\hline-160.00 & -40.00 & 492624.47 & 1774515.26 & 84.04147 \\
\hline-120.00 & .40 .00 & 492689.11 & 1774401.05 & 84.04148 \\
\hline-100.00 & -40.00 & $49272 ! .43$ & 1774343.95 & 84.04149 \\
\hline-60.00 & -40.00 & 492786.07 & 1774229.74 & 84.041 .50 \\
\hline-160.00 & -60.00 & 492.567 .37 & 1774482.94 & $84 .(14151$ \\
\hline-140.00 & -60.00 & 492.599 .69 & 1774425.84 & $\times \quad 4152$ \\
\hline-120.00 & $-6 U .00$ & 4926.32 .01 & 1774368.73 & $8+.14153$ \\
\hline-100.00 & .60 .00 & 492664.33 & 1774311.63 & 84.04154 \\
\hline-200.00 & .80 .00 & 492445.62 & 1774.564 .84 & 84.04155 \\
\hline-18000 & -80.00 & 492477.94 & 1774507.73 & 84.041 .56 \\
\hline-160.00 & $-80 .(x)$ & 492510.26 & 1774450.63 & 84.041 .57 \\
\hline .140 .00 & -80.00 & 492.542 .58 & 1774393.52 & 84.041 .58 \\
\hline .100 .00 & -80.00 & 402607.22 & 1774279.31 & 84.04159 \\
\hline-80.00 & -80.00 & 492639.54 & 1774222.20 & 84.04160 \\
\hline-100.00 & $-100.0 x)$ & 4925.50 .12 & 1774246.90 & 84.144161 \\
\hline-60.00 & -100.00 & 492614.76 & 1774132.78 & 84.194162 \\
\hline$\therefore 20.00$ & -10.00 & 492774.77 & 1774449.53 & $84 .(14175$ \\
\hline-80.00 & $-20.0(x)$ & 492810.86 & 1774.319 .16 & 84.14176 \\
\hline$-60.0(5)$ & $.20 .00)$ & 492843.18 & 1774262.16 & 84.04177 \\
\hline-160.00$)$ & .40 .00 & 492624.47 & 1774515.26 & 84.04178 \\
\hline-120.00 & -40.001 & 492689.11 & 1774401.05 & 84.04179 \\
\hline-100.00 & -40.00 & 492721.43 & 1774343.95 & 84.04180 \\
\hline-60.00 & -40.00 & 492786.07 & 1774229.74 & 84.04181 \\
\hline-160.00 & -60.00 & 492567.37 & 1774482.94 & 84.04182 \\
\hline-140.00 & -60.00 & 492599.69 & 1774425.84 & 84.04183 \\
\hline-120.00 & -60.00 & 4926.32 .01 & 1774368.73 & 84.04184 \\
\hline-100.00 & -60.000 & 492664.33 & 1774311.63 & 84.04185 \\
\hline-200.00 & .80 .00 & 492445.62 & 1774564.84 & 84.04186 \\
\hline-180.00 & $-8(0.0()$ & 492477.94 & $1774.5(07.73$ & 84.04187 \\
\hline-160.00 & -80.00 & 492510.20 & 177445() .63 & 84.14188 \\
\hline-140.00 & .80 .000 & 492.542 .58 & 1774393.52 & 84.04180 \\
\hline-100.00 & -80.00 & $4926(07.22$ & 1774279.31 & 84.04190 \\
\hline$-80 .(x)$ & .80 .00 & 492639.54 & 1774222.20 & 84.04191 \\
\hline-60.00 & -100.00 & 492614.76 & 1774132.78 & $84 .(14192$ \\
\hline-80.00 & -20.00 & 492810.86 & 1774319.16 & 84.04206 \\
\hline-60.00 & -20.000 & 492843.18 & 1774262.06 & 84.04207 \\
\hline-160.00 & .40 .00 & 492624.47 & 1774515.26 & $84 .(14208$ \\
\hline-120.00 & .40 .00 & 492689.11 & 1774401.05 & $84 .(14209$ \\
\hline-100.00 & $.40 .(0)$ & 492721.43 & 1774343.95 & 84.124210 \\
\hline-60.00 & $-40 .(x)$ & 492786.07 & 1774229.74 & 84.04211 \\
\hline-160.00 & -60.000 & 492567.37 & 1774482.94 & 84.114212 \\
\hline-140.00 & $-60 .(x)$ & 492599.69 & 1774425.84 & 84.11421 .3 \\
\hline-120.00 & $-60.0 \times 0$ & 492632.01 & 1774368.73 & 84.114214 \\
\hline-100.00 & -60.00 & 492664.33 & 1774311.63 & $84 .(14215$ \\
\hline-200.00 & .80 .00 & 492445.62 & 1774364.84 & 84.14216 \\
\hline-180.00 & .80 .00 & 492477.94 & 1774507.73 & 84.04217 \\
\hline .140 .00 & $.80 .(x)$ & 492542.58 & 1774393.52 & 84.04218 \\
\hline-100.00 & -80.00 & 492607.22 & 1774279.31 & 84.04219 \\
\hline
\end{tabular}


Table 3. Sampling grid coordinates, New Mexico State Plane corrdinates and radionuclide sample numbers for the 1984 survey of MDA.T. (Con't.)

\begin{tabular}{|c|c|c|c|c|}
\hline \multicolumn{2}{|c|}{ Sample Grid System } & \multicolumn{2}{|c|}{ NMSP System } & \multirow{2}{*}{$\begin{array}{l}\text { Sample } \\
\text { Number }\end{array}$} \\
\hline Easting & Northing & Easting & Northing & \\
\hline-180.00 & -40.00 & 492.592 .15 & 1774572.37 & 84.04284 \\
\hline .200 .00 & -40.00 & 492559.84 & 1774629.47 & $84 .(14285$ \\
\hline-40.00 & -60.00 & 492761.29 & 1774140.31 & 84.04286 \\
\hline .60 .00 & -80.00 & 492671.86 & 177416.5 .10 & 84.04287 \\
\hline-220.00 & -80.00 & 492413.31 & 1774621.94 & 84.04288 \\
\hline-240.00 & .80 .00 & 492380.99 & 1774679.05 & 84.04289 \\
\hline .100 .00 & -20.00 & 492778.54 & 1774376.27 & 84.04290 \\
\hline-80.00 & -100.00 & 492582.44 & 1774189.88 & $84.0429 !$ \\
\hline-120.00 & -100.00 & 492517.80 & $17743(14.10$ & 84.04292 \\
\hline-140.00 & -100.00 & 492485.48 & 1774.361 .20 & 84.04293 \\
\hline-160.00 & -100.00 & 492453.16 & 1774418.31 & 84.04294 \\
\hline-180.00 & .100 .00 & 492420.84 & 1774475.41 & 84.04295 \\
\hline .200 .00 & -100.00 & 492388.52 & 1774532.52 & 84.04296 \\
\hline-220.00 & -100.00 & 492356.20 & 1774.589 .62 & 84.04297 \\
\hline-40.00 & -40.00 & 492818.39 & 1774172.63 & 84.04303 \\
\hline .200 .00 & -40.00 & 492559.84 & 1774629.47 & $84 .(04305$ \\
\hline-40.00 & -60.00 & 492761.29 & 1774140.31 & 84.04306 \\
\hline .60 .00 & -80.00 & 492671.86 & 177416.5 .10 & 84.04307 \\
\hline .220 .00 & -80.00 & 492413.31 & 1774621.94 & 84.04308 \\
\hline-240.00 & -80.00 & +42380.99 & 1774679.05 & $84.04 .3(0)$ \\
\hline-100.00 & -20.00 & 492778.54 & 1774.376 .27 & 84.04310 \\
\hline-80.00 & .100 .00 & 492582.44 & 1774189.88 & 84.04311 \\
\hline-120.00 & $-100,00$ & 492517.80 & 1774304.10 & $84 .(14312$ \\
\hline-140.00 & -100.00 & 492485.48 & 1774361.20 & 84.04313 \\
\hline-160.00 & -100.00 & 492453.16 & 1774418.31 & 84.04314 \\
\hline-180.00 & -100.00 & 492420.84 & 1774475.41 & 84.04315 \\
\hline .200 .00 & -100.00 & 492388.52 & 1774532.52 & 84.04316 \\
\hline .220 .00 & .100 .00 & 492356.20 & 1774.589 .62 & 84.04317 \\
\hline-40.00 & -40.00 & 492816.39 & 1774172.62 & $84 .(14323$ \\
\hline$-40 .(x)$ & .180 .00 & 492418.6 .5 & 1773946.4() & 84.04324 \\
\hline-200.00 & -40.00 & 4025.59 .84 & 1774629.47 & $84 .(143.325$ \\
\hline-40.00 & $-60.00)$ & 492761.29 & 1774140.31 & $84 .(14326$ \\
\hline-60.00 & $-80.0 n$ & 492671.86 & 1774165.10 & 84.04327 \\
\hline-220.00 & .80 .00 & 492413,31 & 1774621.94 & $84 .(14328$ \\
\hline .240 .00 & .80 .00 & 492380.99 & 1774679.05 & $84 .(14329$ \\
\hline-100.00 & -20.00 & 492778.54 & 1774376.27 & 84.04330 \\
\hline-80.00 & -100.00 & 492.582 .44 & 1774189.88 & 84.04331 \\
\hline-120.00 & -100.00 & 492517.80 & $17743(24.10$ & 84.1143332 \\
\hline-140.00 & -100.00 & 492485.48 & 1774361.20 & 84.104 .333 \\
\hline-160.00 & .100 .00 & 4924.53 .16 & 1774418.31 & 84.0433 .34 \\
\hline-180.00 & -100.00 & 492420.84 & 1774475.41 & $84 .(1433.35$ \\
\hline .200 .00 & .100 .00 & $4 \circlearrowleft 2388.52$ & 17745.32 .52 & 84.144 .336 \\
\hline .220 .00 & $-1(0) .00$ & 492356.20 & 1774.589 .62 & 84.04 .337 \\
\hline
\end{tabular}


Table 4. Original and adjusted reference points for 1986 survey of MDA-T.

\begin{tabular}{lcc}
\hline \multicolumn{1}{c}{$\begin{array}{c}\text { Sample grid system } \\
\text { (Easting, northing) }\end{array}$} & Easting & $\begin{array}{c}\text { NMSP Coordinates } \\
\text { Northing }\end{array}$ \\
\hline Qrivinal survey reference points: & & \\
0,0 & 492815.76 & 1774166.10 \\
$-70,10$ & 492607.15 & 1774253.84 \\
$-40,30$ & 492715.08 & 1774295.63 \\
Adiusteit survey reference points: & & \\
0,0 & 492825.76 & 1774156.10 \\
$-70,10$ & 492607.15 & 1774227.34 \\
$-40,30$ & 492725.08 & 1774285.63 \\
\hline \hline
\end{tabular}

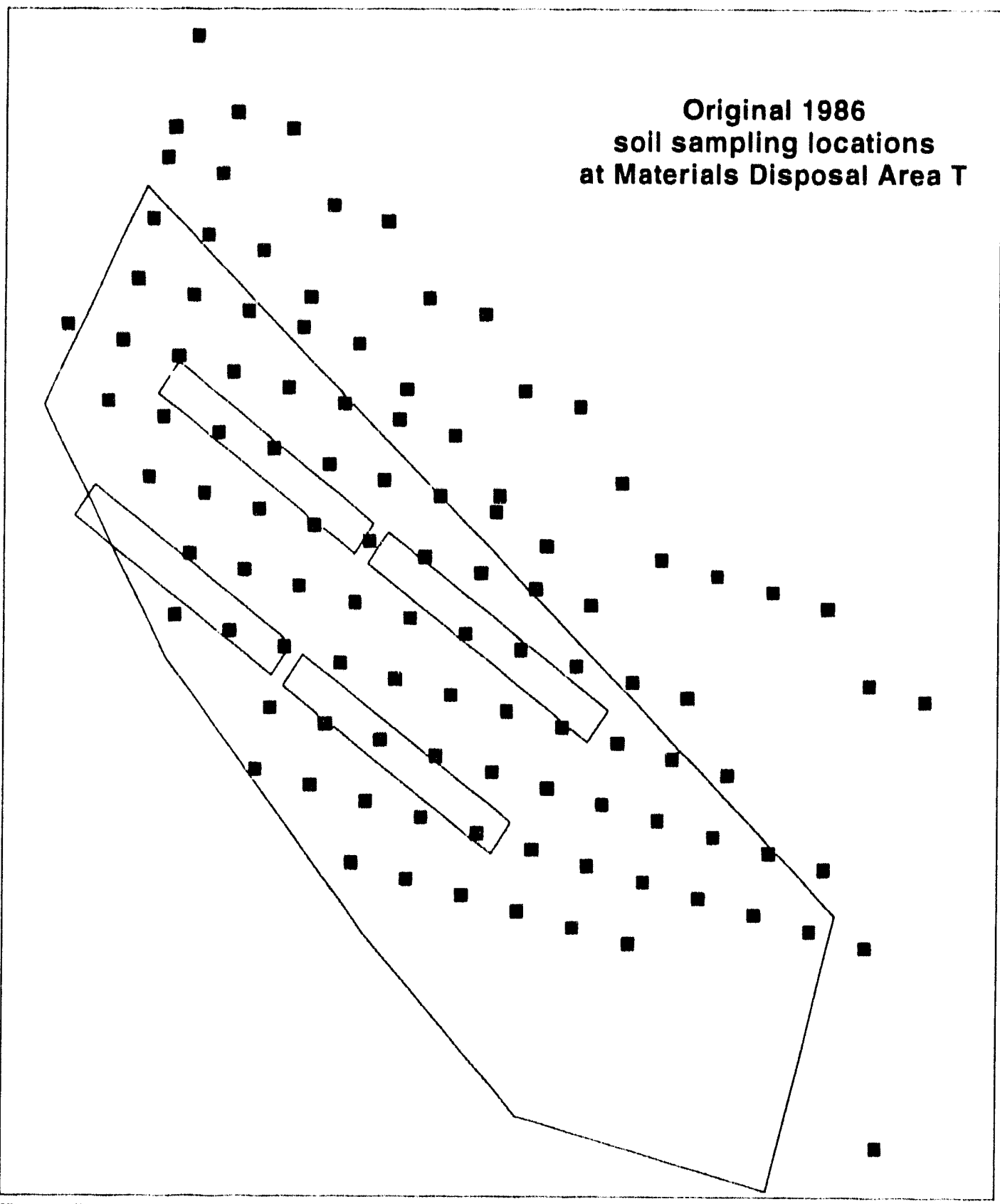

Fig. 8. Projected sample locations for 1986 survey of Materials Disposal Area T based on original survey reference points (Table 4) 


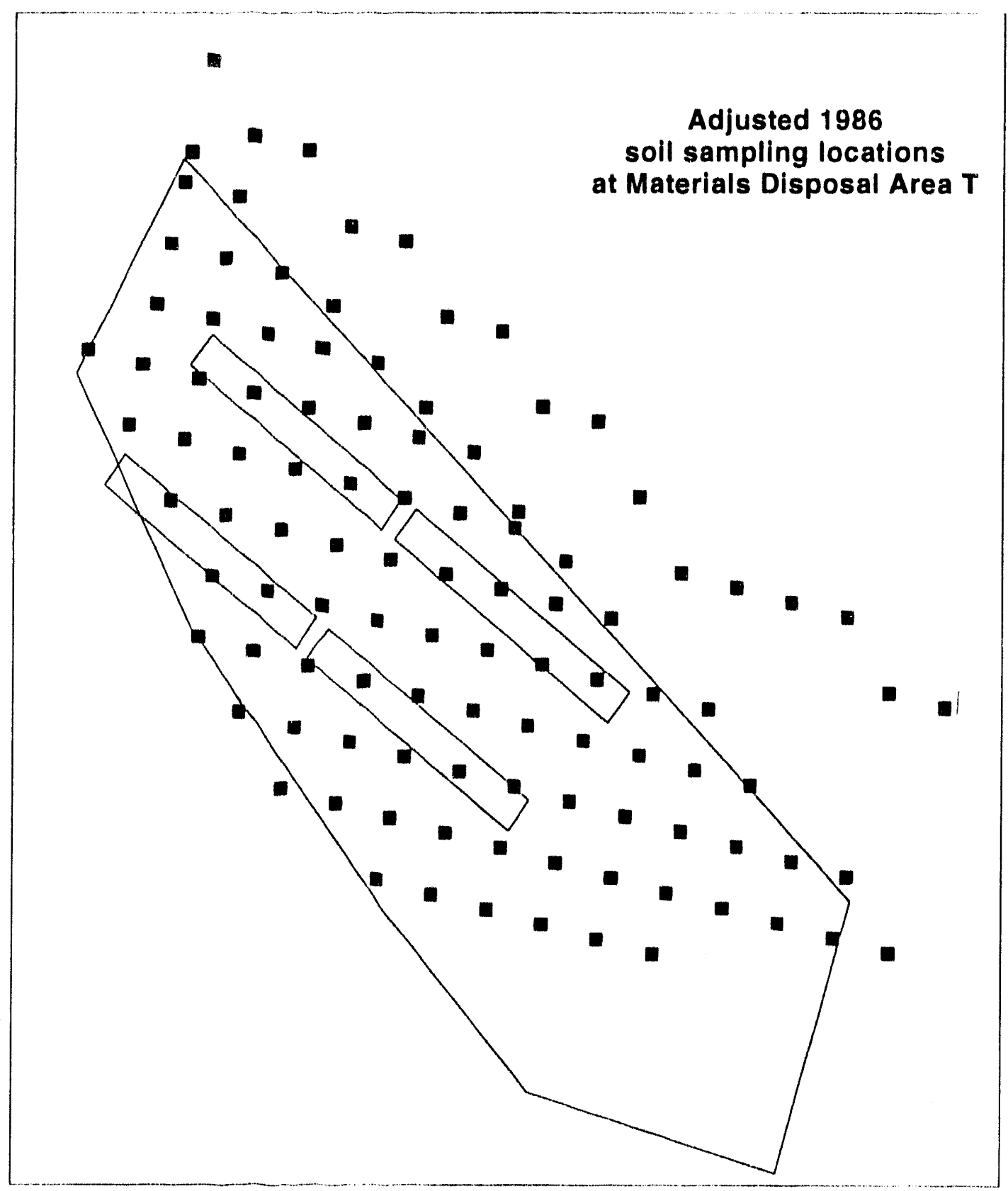

Fig. 9. Estimated locations for 1986 survey of Materials Disposal Area T based on adjusted survey reference points (Table 4). 
Table 5. Sampling grid coordlnates, New Mexico Stute Plane adjusted coordinates and ri dionuclide sample numbers for the 1986 surveys of MDA-T.

\begin{tabular}{|c|c|c|c|c|}
\hline \multicolumn{2}{|c|}{ Sample Grid System } & \multicolumn{2}{|c|}{ NMSP System } & \multirow{2}{*}{$\begin{array}{l}\text { Sumple } \\
\text { Number }\end{array}$} \\
\hline Eastlne & Northing & Easting & Northine & \\
\hline-50.00 & 50.00 & 492701.44 & 1774351.97 & 86.11867 \\
\hline-60.00 & 50.00 & 492669.42 & 1774359.12 & 86.11868 \\
\hline .70 .00 & 50.00 & 492637.40 & 1774366.28 & 86.11869 \\
\hline .70 .00 & 60.00 & 492644.56 & 1774398.30 & 86.11870 \\
\hline-80.00 & 60.00 & 492612.54 & 1774405.45 & 86.11871 \\
\hline .90 .00 & 60.00 & 492580.52 & 1774412.61 & 86.11872 \\
\hline-100.00 & 60.00 & 492548.50 & 1774419.76 & 86.11873 \\
\hline-110.00 & 60.00 & 492516.48 & 1774426.92 & 86.11874 \\
\hline-120.00 & 60.00 & 492484.46 & 1774434.07 & 86.18875 \\
\hline-130.00 & 60.00 & 492452.45 & 1774441.23 & 86.11876 \\
\hline-140.00 & 60.00 & 492420.43 & 1774448.38 & 86.11877 \\
\hline-80.00 & 70.00 & 492619.69 & 1774437.47 & 86.11878 \\
\hline .90 .00 & 70.00 & 492587.68 & 1774444.63 & 80.11879 \\
\hline-100.00 & 70.00 & 492555.66 & 1774451.78 & 86.11880 \\
\hline-110.00 & 70.00 & 492523.64 & 1774458.93 & 86.11881 \\
\hline-120.00 & 70.00 & 492491.62 & 1774466.09 & 86.11882 \\
\hline-130.00 & 70.00 & 492459.60 & 1774473.24 & 8611883 \\
\hline-140.00 & 70.00 & 492427.58 & 1774480.40 & 86.11884 \\
\hline-150.00 & 70.00 & 492395.56 & 1774487.55 & 86.11885 \\
\hline-100.00 & 80.00 & 492562.81 & 1774483.80 & 86.11886 \\
\hline-110.00 & 80.00 & 492530.79 & 1774490.95 & 86.11887 \\
\hline .120 .00 & 80.00 & 492498.77 & 1774498.11 & 86.11888 \\
\hline-130.00 & 80.00 & 492466.76 & 1774505.26 & 86.11889 \\
\hline-140.00 & 80.00 & 492434.74 & 1774.512 .42 & 86.11890 \\
\hline-150.00 & 80.00 & 492402.72 & 1774519.57 & 86.11891 \\
\hline-160.00 & 80.00 & 492370.70 & 1774526.73 & 86.11892 \\
\hline-110.00 & 90.00 & 492537.95 & 1774522.97 & 86.11893 \\
\hline-120.00 & 90.00 & 492505.93 & 1774530.13 & 86.11894 \\
\hline-130.00 & 90.00 & $4924 ; 3.91$ & 1774537.28 & 86.11895 \\
\hline-140.00 & 90.00 & 492441.89 & 1774544.44 & 80.11890 \\
\hline 150.00 & 90.00 & 492409.87 & 1774551.59 & 86.11897 \\
\hline-160.00 & 90.00 & 492377.85 & 1774558.79 & 86.11898 \\
\hline-170.00 & 90.00 & 492345.84 & 1774565.90 & 86.11890 \\
\hline-130.00 & 100.00 & 492481.07 & 1774569.30 & 86.11900 \\
\hline-140.00 & 100.00 & 492449.05 & 1774.576 .46 & 86.11901 \\
\hline-150.00 & 100.00 & 492417.03 & 1774583.61 & 86.11902 \\
\hline-160.00 & 100.00 & 492385.01 & 1774590.77 & 86.11903 \\
\hline-150.00 & 110.00 & 492424.18 & 1774615.63 & 86.11904 \\
\hline-160.00 & 110.00 & 492392.16 & $17746,22.78$ & 86.11905 \\
\hline-160.00 & 110.00 & 492399.32 & 1774654.80 & 86.11906 \\
\hline-10.00 & 30.00 & 492815.21 & 1774259.31 & 86.11907 \\
\hline-20.00 & 40.00 & 492790.34 & 1774298.48 & 86.11908 \\
\hline-40.00 & 50.00 & 492733.46 & 1774344.81 & 86.11909 \\
\hline-50.00 & 60.00 & 492708.60 & 1774383.99 & 86.11910 \\
\hline-60.00 & 60.00 & 492676.58 & 177439114 & 86.11911 \\
\hline .70 .00 & 70.00 & 4926.51 .71 & 1774430.32 & 86.11912 \\
\hline-80.00 & 80.00 & 492626.85 & 1774469.49 & 86.11913 \\
\hline-90.00 & 80.00 & 492594.83 & 1774476.64 & 86.11914 \\
\hline-90.00 & 90.00 & 49260199 & 1774508.66 & 8611915 \\
\hline-100.00 & 90.00 & 492569.97 & 1774515.82 & 86.11916 \\
\hline-110.00 & 100.00 & 492545.10 & 1774554.99 & 86.11917 \\
\hline-120.00 & 100.00 & 492513.08 & 1774.562 .15 & 86.11918 \\
\hline-130.00 & 110.00 & 492488.22 & 1774601.32 & 86.11919 \\
\hline-140.00 & 110.00 & 492456.20 & 1774608.47 & 86.11920 \\
\hline-150.00 & 120.00 & 492431,34 & 1774647.65 & 86.1192 \\
\hline-160.00 & 130.00 & 492406.47 & 1774686.82 & 86.11 \\
\hline-10.00 & 70.00 & 492843.83 & 1774387.39 & $86.11 !$ \\
\hline .20 .00 & 70.00 & 492811.81 & 1774394.54 & $86.115: 4$ \\
\hline .30 .00 & 80.00 & 492786.94 & 1774433.71 & 86.11925 \\
\hline-40.00 & 80.00 & 492754.92 & 1774440.87 & 8611926 \\
\hline-50.00 & $80 .(x)$ & 492722.91 & 1774448.02 & 86.11927 \\
\hline$-60 .(x)$ & 80.00 & 492690.89 & 177445518 & 86.11928 \\
\hline .70 .00 & $00 .(x)$ & 49266602 & 177449435 & 80.11920 \\
\hline-80.00 & 100.00 & 49264116 & 177453353 & 80.11930 \\
\hline .90 .00 & 100.00 & 492609.14 & 1774540.68 & 80.11931 \\
\hline-100.00 & 110.00 & 492584.28 & 1774579.85 & 80.11932 \\
\hline-110.00 & 110.00 & 492552.26 & 1774587.01 & 86.11933 \\
\hline-120.00 & 120.00 & 492527.39 & 1774626.18 & 86.11935 \\
\hline-130.00 & 120.00 & 492495.38 & 1774633.34 & 8611936 \\
\hline-140.00 & 130.00 & 492470.51 & 1774672.51 & 86.11937 \\
\hline-150.00 & 130.00 & 492438.49 & 1774679.67 & 8611938 \\
\hline-160.00 & 140.00 & 492413.63 & 1774718.84 & 86.11939 \\
\hline
\end{tabular}




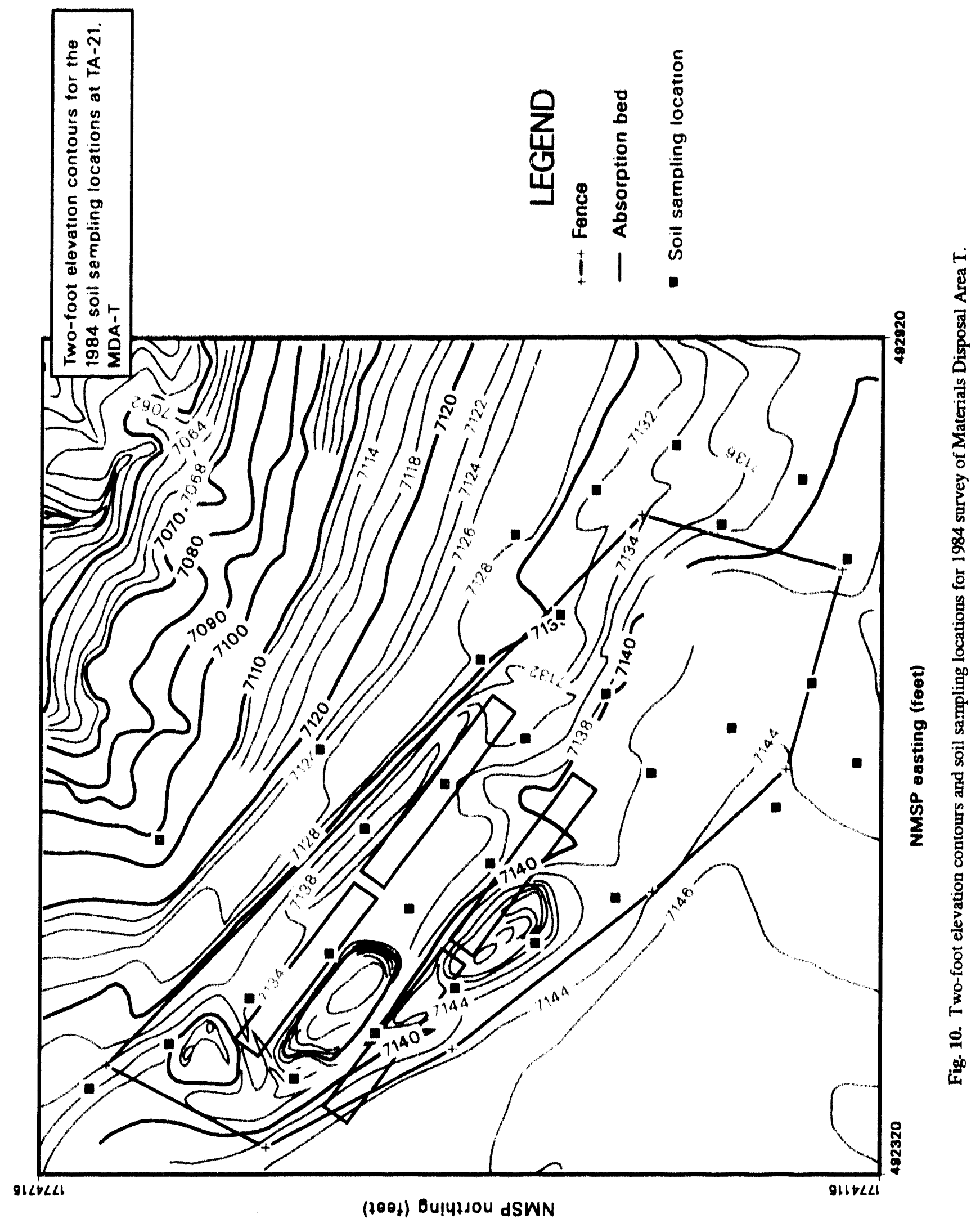




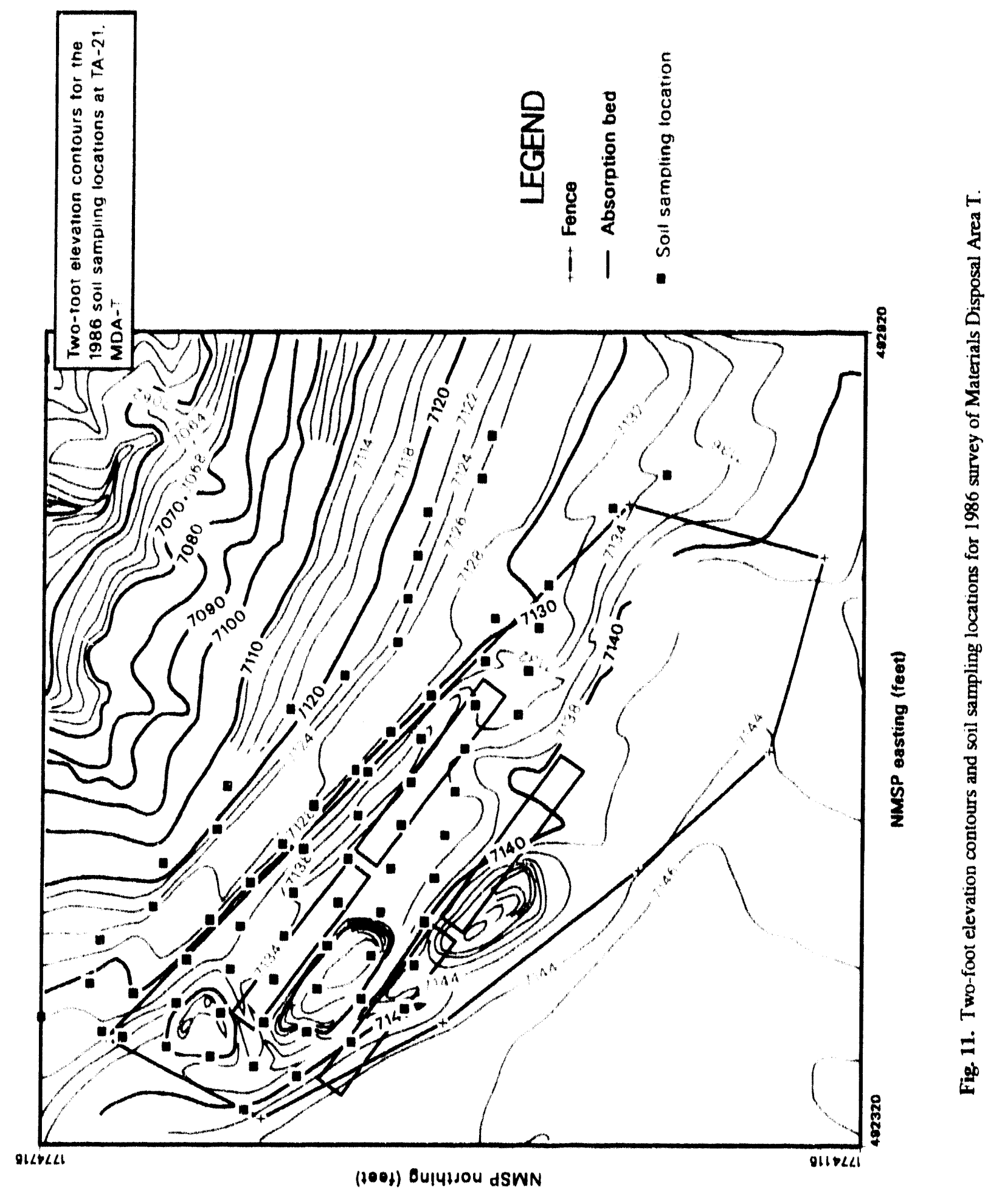




\section{B. Survey results for soll radionuclide concentrations}

The Laboratory's Environmental Surveillance (iroup has monitored regional soils located away from Los Alamos 10 provide natural and worldwide lallout background it,i., rmation for several radionuclides (13. 14). This data is summarized in Tahle 6 and was used II evaluate the 1984 and 1986 survey results at MDA. T. Radionuclide concentration contours were selected on the basis of (1) radionuclide concentrations below the mean background concentration, and (2) radionuclide concentrations as large as the mean background concentration plus twice the standard deviation of the mean background concentration. Thus, the latter contours presented in the following subsections of this report will represent the upper limit background concentration for that particular radionuclide (Table 6). The upper limit background level calculated this way leads (1) the statistical expectation that only 1 in 4() hackground samples analyzed will exceed the upper background concentration.

\section{(1) The 1984 Survey Kesults}

Since there were so few radionuclide assay results for samples collected from the 0.1 cin depth, this data was not considered in this report.

The tritium concentration contours are presented for the 1984 soil survey of MDA.T for the $1.10 \mathrm{~cm}$ sampling depth and for the $10.30 \mathrm{~cm}$ sampling depth in Figures 12 and 13, respectively. Based on these results, most of the soil samples collected in this survey were either below mean background concentration in soil (corresponding (o) a gray color in the ligures or mean) or hackground concentration plus twice the standard deviation of the mean background concentration (corresponding to a blue color in the figures). Tritium concentrations above this latler upper limil of background were found in only 4 locations at the $1.10 \mathrm{~cm}$ sampling depth (lig. 12) and at only iwo locations at the deeper depth (Fig. 13). Most of the elevated tritium concentrations were found in samples collected within the fenced area of this disposal site. The highest concentrations were found in the deeper stumples collected hetween the northern site fence and Absorption Bed 4 (ligs. 12 and 13). Due (o) the short half-life of Iritium, the tritium concentrations currently in these same samples would be about half of the concentrations determined in 1984

The plutonium concentration contours are presented in Figures 14 through 17 for the 1984 survey. In strong contrast (o) the tritium data, most of the samples collected were considerably above the upper limits of hackground

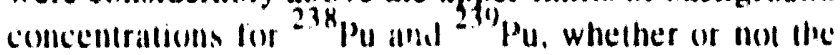
samples were collected inside or outside of this disposal sile's fence. In addition, the plutonium concentrations al hoth sampling depths usually were similar: a large change in concentrations did not usually occur with depth. The highest ${ }^{238} \mathrm{P} u$ concentrations ( 1.0 . $10 \mathrm{p(i/g}$ contour. corresponding to a contour with a yellow color in ligigs. 14 and 15) occurred at two locations above the disposal shafts and at one location within the old ( MP runway (oncentrations of soil ${ }^{238} \mathrm{Pu}$ ranging from (0.0) (o) $1 \mathrm{nci} / \mathrm{g}$ (contours with blue green and dark green colors) dominated the areas to the north and south of the disposal silc, as well ats wilhin the fence

Table 6. Summary of Background Concentrations of Radlonuclides in Solls of Northern New Mexico $(13,14)$.

\begin{tabular}{|c|c|c|c|}
\hline Radionuclide & Units & $\begin{array}{c}\text { Mean } \\
\text { Concentration } \\
\end{array}$ & $\begin{array}{l}\text { Upper limit of Background } \\
\text { (mean concentration plus } 2 \\
\text { standard deviations) }\end{array}$ \\
\hline${ }^{3} 11$ & 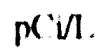 & $2(x)(1)$ & $72(x)$ \\
\hline $238 \mathrm{Pu}$ & $p(i / g$ & $0(x) 1$ & $0.1 \times 05$ \\
\hline $239 \mathrm{Pu}$ & $p(i / g$ & (). $(x) 7$ & 0.025 \\
\hline $241 \wedge \mathrm{m}$ & $p(i / g$ & $0 .(x) 7$ & 0.023 \\
\hline
\end{tabular}




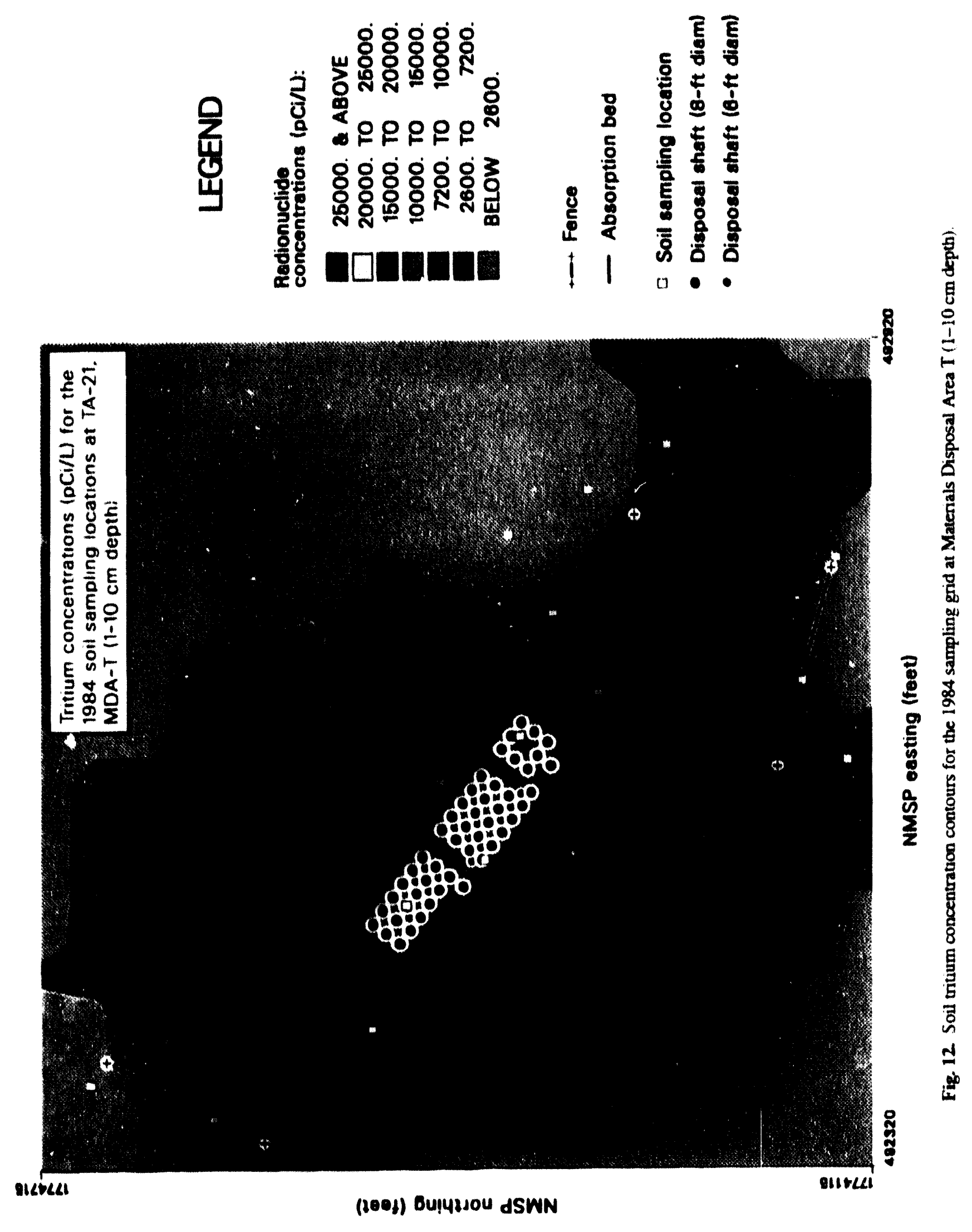




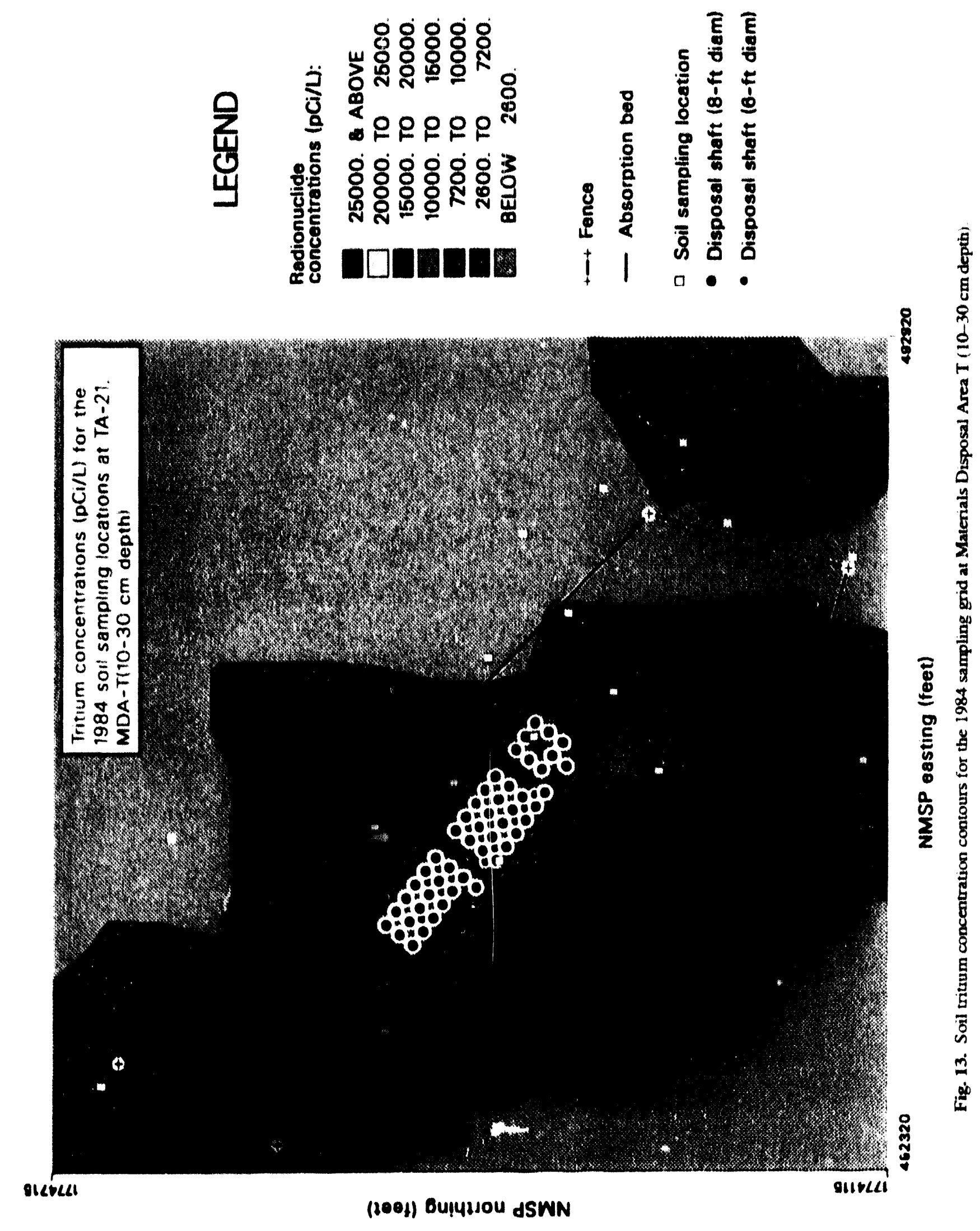




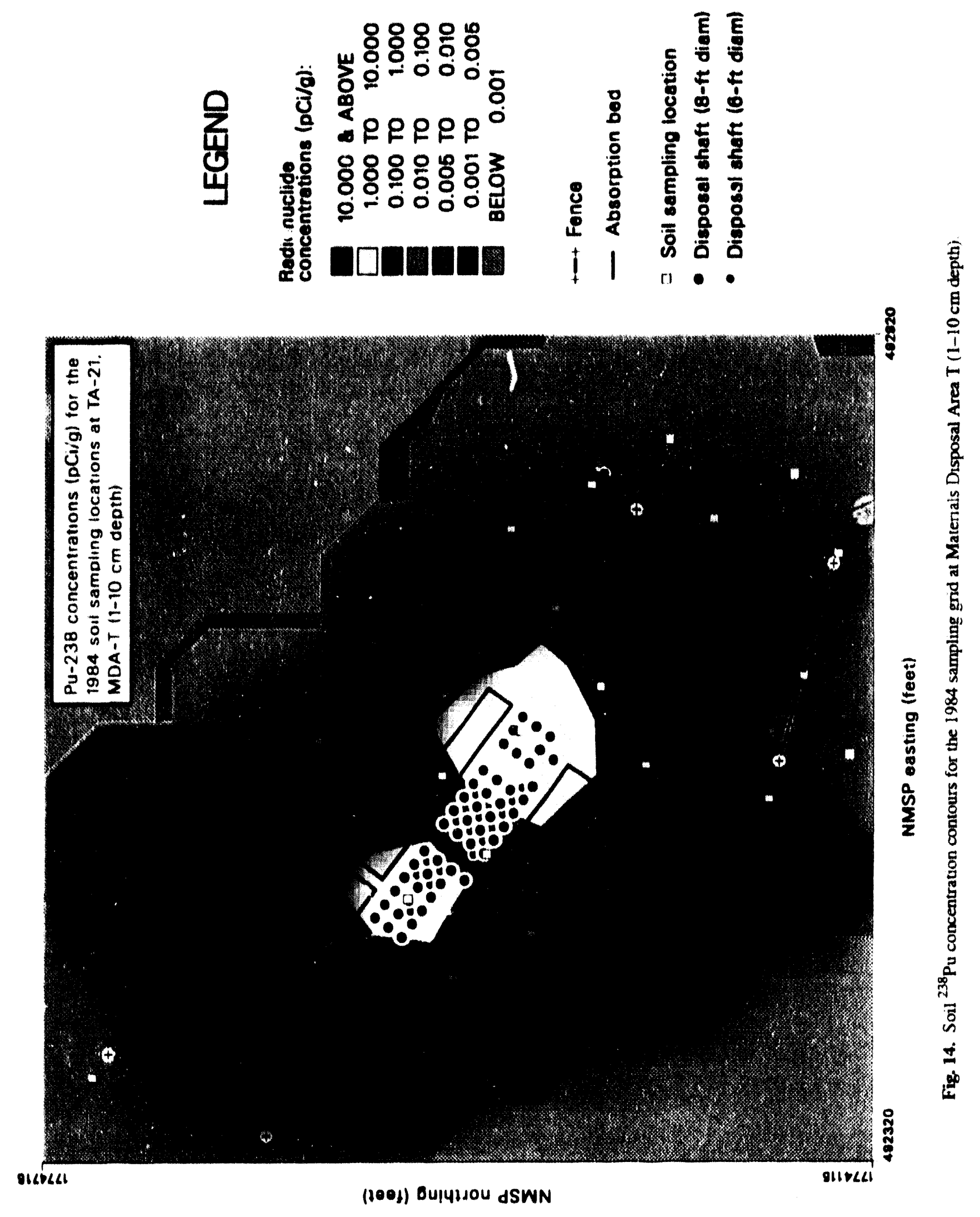




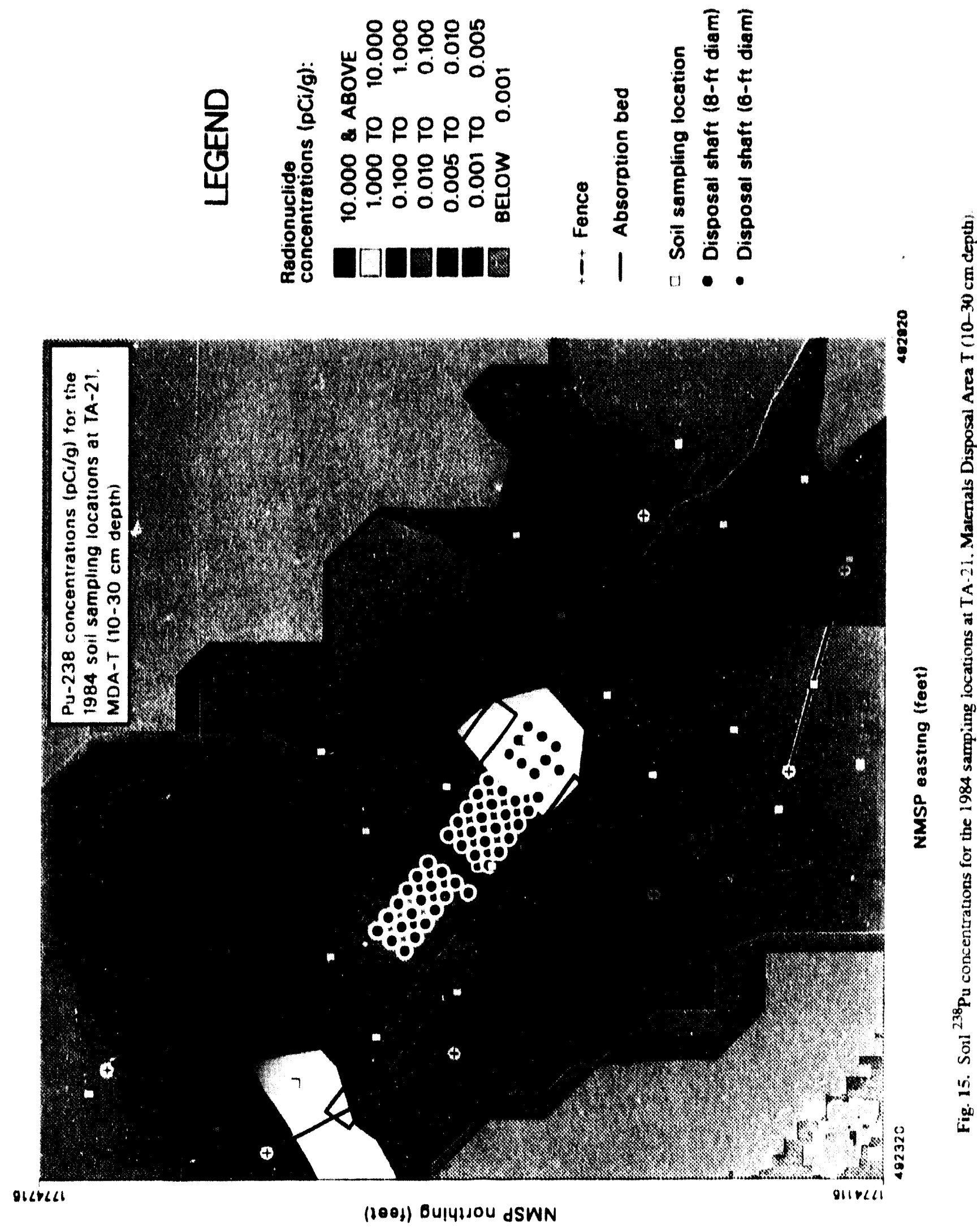



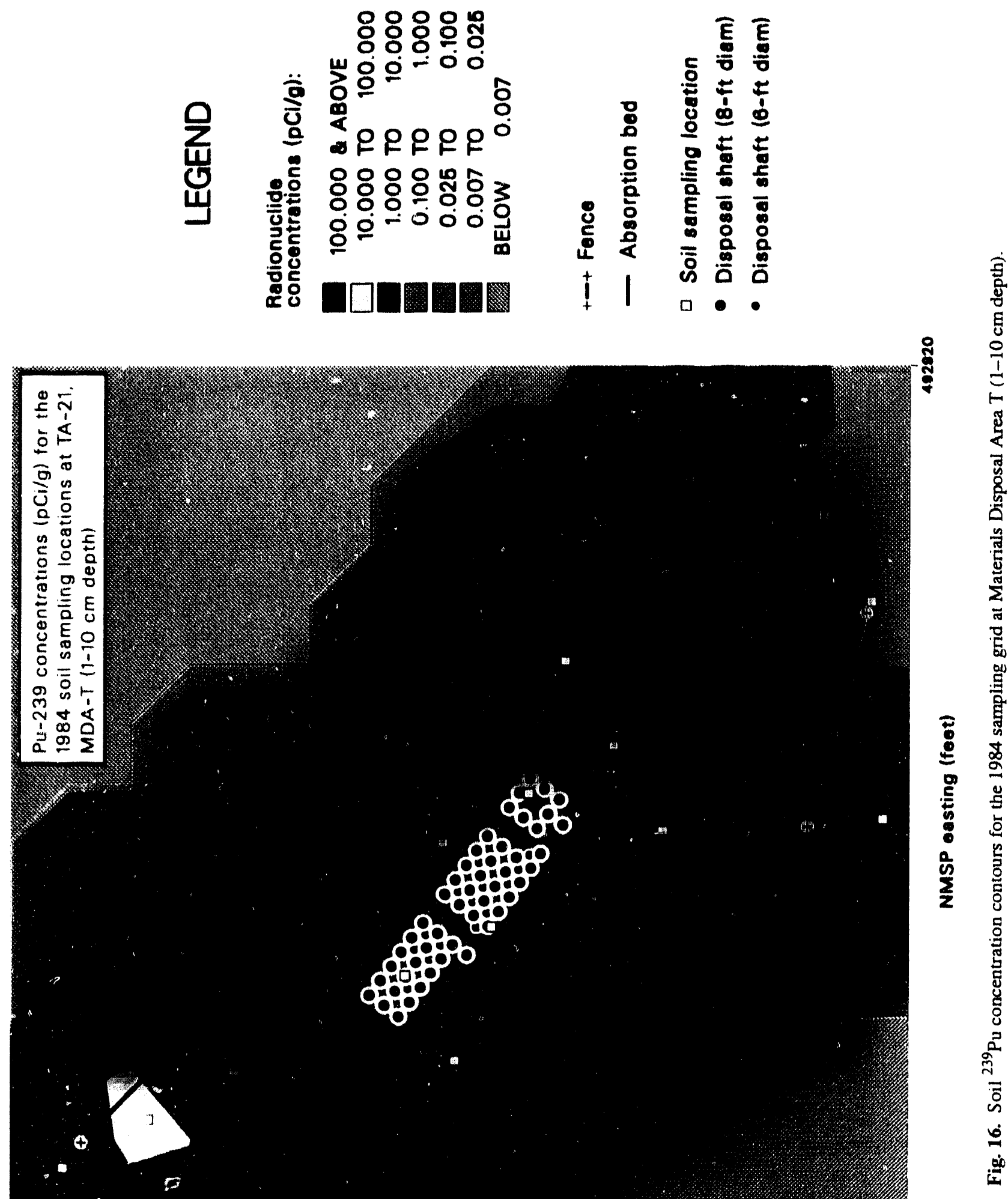


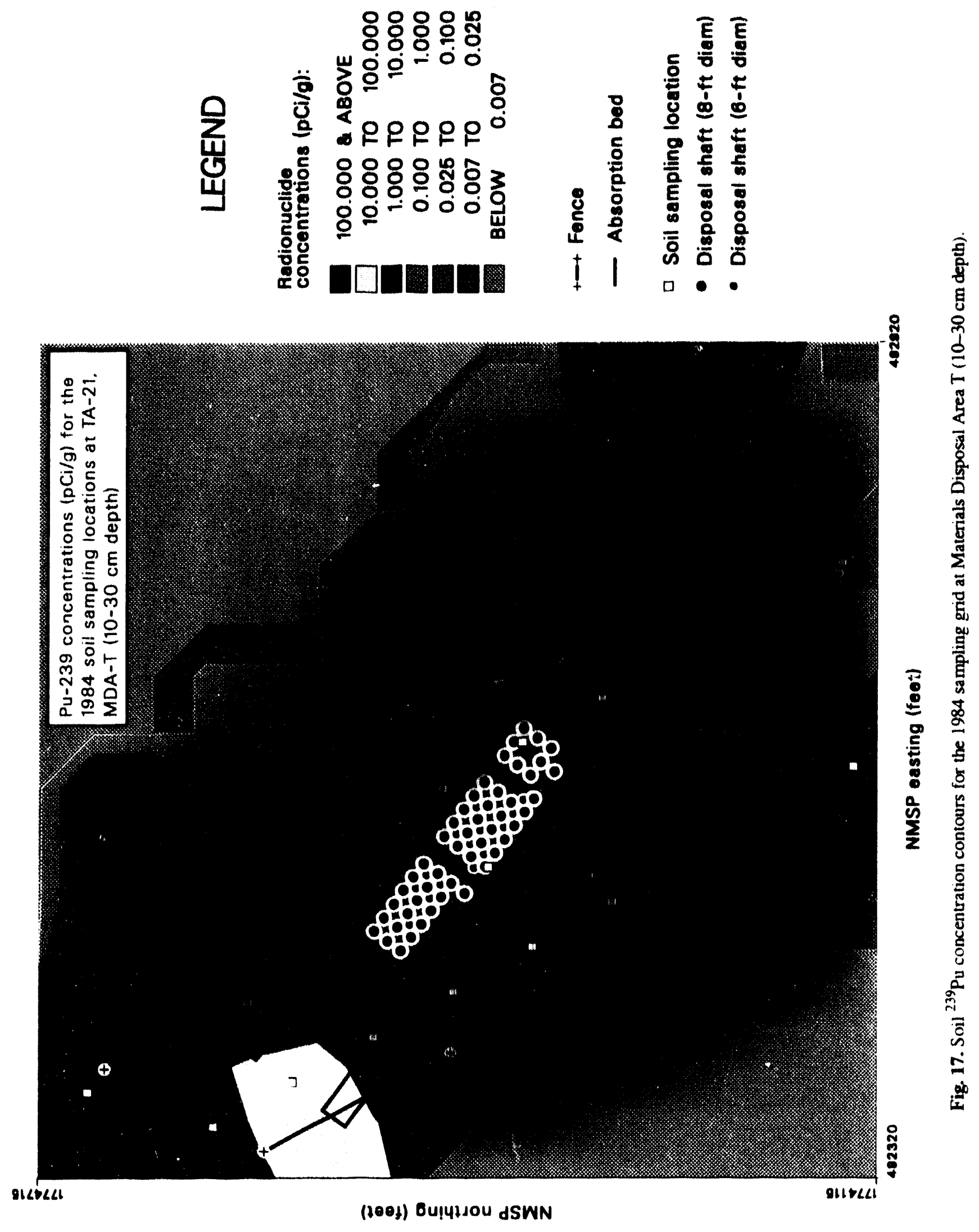


The highest concentrations of ${ }^{239}$ Pu were found above the old CMP runway, in the western portion of MDA-T (Figs. 16 and 17). These are represented by ${ }^{239} \mathrm{Pu}$ concentration in these surface soil samples ranging from 10 10 $100 \mathrm{pCi} / \mathrm{g}$, designated as the yellow comtours in Figures 16 and 17. Soil samples with 4(). 10 10(1)-fold increased ${ }^{239} \mathrm{Pu}$ over the upper limil for background concentrations (contour with the dark green color in Figs. 16 and 17) seemed to be more dominant over the disposal site than corresponding contours for ${ }^{238} \mathrm{Pu}$ (Figs. 14 and 15). Although the exact reason for this observation is unknown at this time, a partial explanation may he derived from the waste use history of the site as presented earlier in this report: 1 wo- to four-fold inore ${ }^{239} \mathrm{Pu}$ was in the waste than ${ }^{238} \mathrm{Pu}$ (on a radionuclide activity basis).

Another important point should he made to clarify the overall significance of the plutonium data collected in 1984. As we pointed out earlier, the soil samples collected only represent what occurred on the mesa tops, ice at elevations ranging from $7146107100 \mathrm{fl}$ at MDA.T. None of these samples reflect the impact of the treated and untreated liquid wastes discharged (o) D) ( anyon (to the north of the disposal sile)

\section{(2) The 1986 Survey Results}

The 1986 survey of the soil radionuclides at MI)A-1 involved samples collected at only one sampling depth. $0.5 \mathrm{~cm}$. Whereas the 1984 sampling locations were on 20) in centers, the 1986 soil samples were collected $10 \mathrm{~m}$ apart, thus improving the accuracy of the radionuclide concentration contours

Because of the mote detailed data collected in this survey compared with the 1984 survey, larger land areas were found with higher plutonium concentrations than in the 1984 survey Thus, when the radionuclide concentration contours were estimated for the disposal site larger land areas could be interconnected in more comprehensive palten than could he accomplished in the 1984 servey. Ilsing the ${ }^{238} \mathrm{Pu}$ concentration contours in the 1 10 $10 \mathrm{pci} / \mathrm{g}$ range (contours wilh the yellow color) as an example, the 1986 survey results show a northeaslsouthwest trending yellow contour proceeding across the western end of MI)A-I encompassing an area of higher concentrations to the south (lig. 18). This entire area was influenced by water erosion which occurred across this end of the disposal area for several years ${ }^{23 K}$ Pu and ${ }^{230} \mathrm{Pu}$ (Fig. 19) associated wilh soil was evidently transporled across the western portion of the site, proceeded in a southeastern direction along the fence (which is south of the north perimeter road adjacent to the north fence of the disposal site), crossed the road to the north of the site, and proceeded down the naturally-oceurring drainage way starting hetween the $7120 \mathrm{ft}$ and 7110 fi elevation contours (sec lig. 11).

Another important observation concerning the soil plutonium concentration contours involves the sampling results north of the north disposal site fence, an area characterized by an undisturbed pinyon juniper woodland. Except for the soil erosion phenomena described ahove. the samples collected north of the north perimeter road were almost consistently within the dark green-colored contours in Figures 18 and 19. This meant that soil ${ }^{238} \mathrm{Pu}$ and ${ }^{239} \mathrm{Pu}_{\mathrm{u}}$ concentrations were consistently $0.1101 .0 \mathrm{pci} / \mathrm{g}$ and $1 \mathrm{l}(0) 10 \mathrm{p(i/g}$. respectively. Estimates of the ratios of ${ }^{231} \mathrm{Pu} 10{ }^{238} \mathrm{Pu}$ were made for the samples collected across this area (liig. 2()), which demonstrate consistently observed ratios of 5 to 25 . Although the reason for this is not fully understood at this time, this area probably received local airborne fallout from DP sile which influenced this entire area. It is also possible that liquid effluents originally contained in absorption heds 3 and 4 overflowed during the early waste history of the site, and plutonium was traniported to the low-elevation areas north of the disposal area. The plutonium ratios presented in Figure 20 suggest that more ${ }^{39}$ Pu was contained in the surface soils than ${ }^{23 k} \mathrm{Pu}$ in the western portion of the disposal area. The reason for this observation is also not fully understood at this time, hut the fact that the disposal shafts contained much lower ${ }^{239} \mathrm{Pu} /{ }^{238}$ Pu ratios suggests an alternative source term. This alternate source term could have involved a high ${ }^{234}$ P'u source which migraled into the disposal site from drainage areas west of this disposal site via sile runon near the southwestern corner of the sile. Allhough ${ }^{241}$ Am assalys were not performed for the soil sitmples collected in 1984, this was a major concern in the 1986 survey (ligh. 21) Very large announts (1) ${ }^{24}$ Am were processed in the pug mill operallons al this sile, especially within the (MPs. It is not surprising then that the soils around the areas where the CMPs were filled with a plastic-wrapped tire hose contained the highest ${ }^{241}$ Am concentrations found at the site (notice the dark green contour centered at the western end of the disposal shafl ficld) 


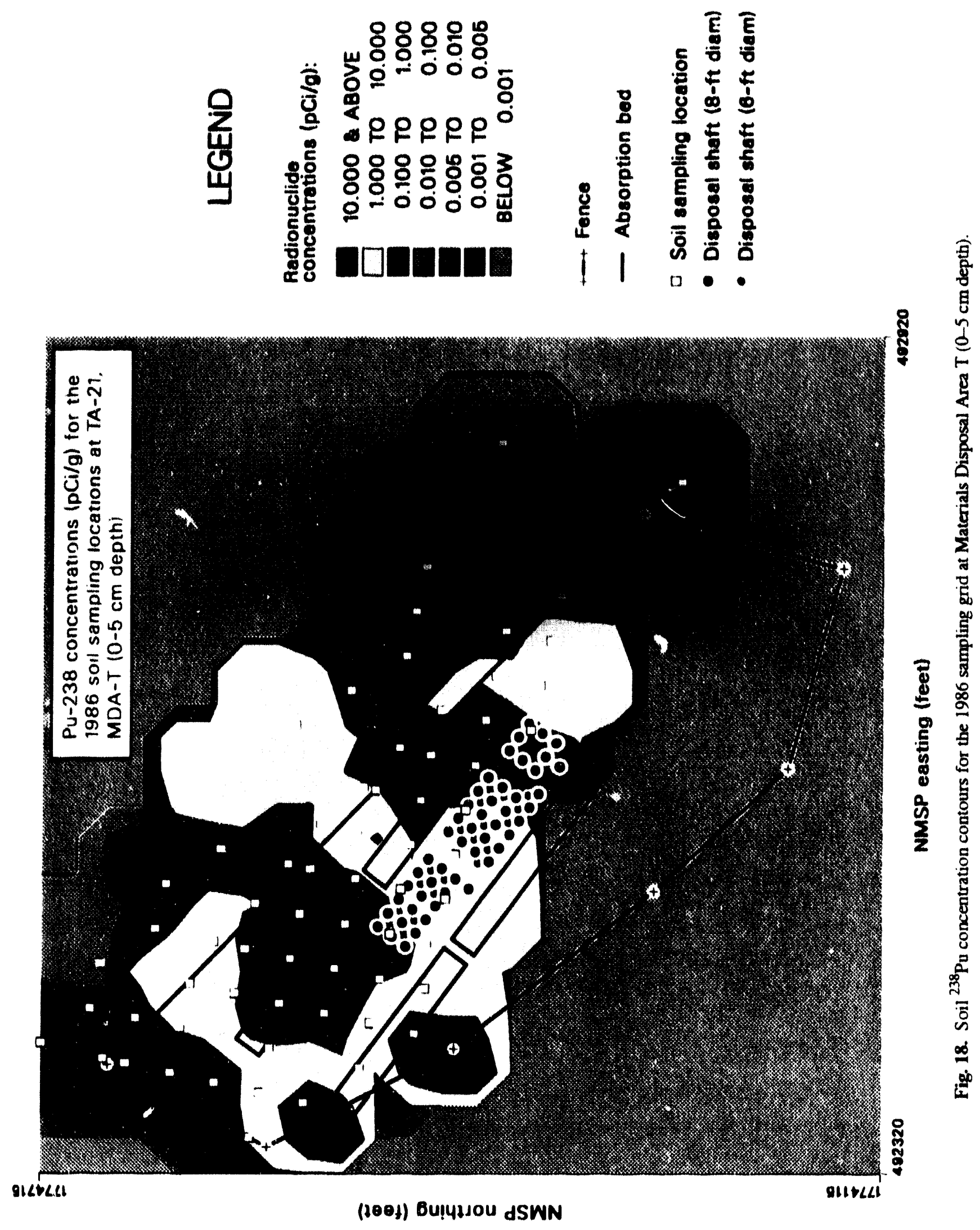




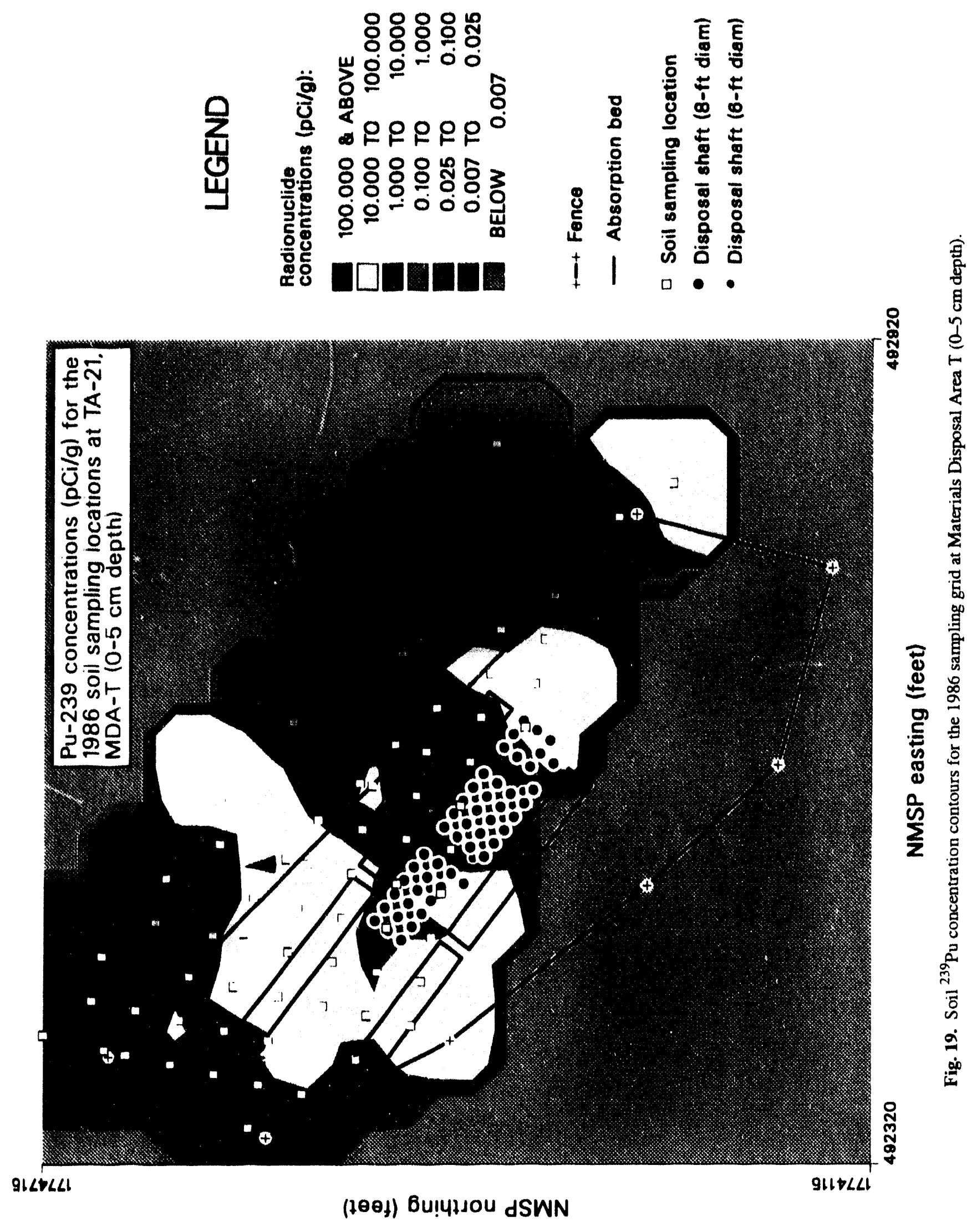




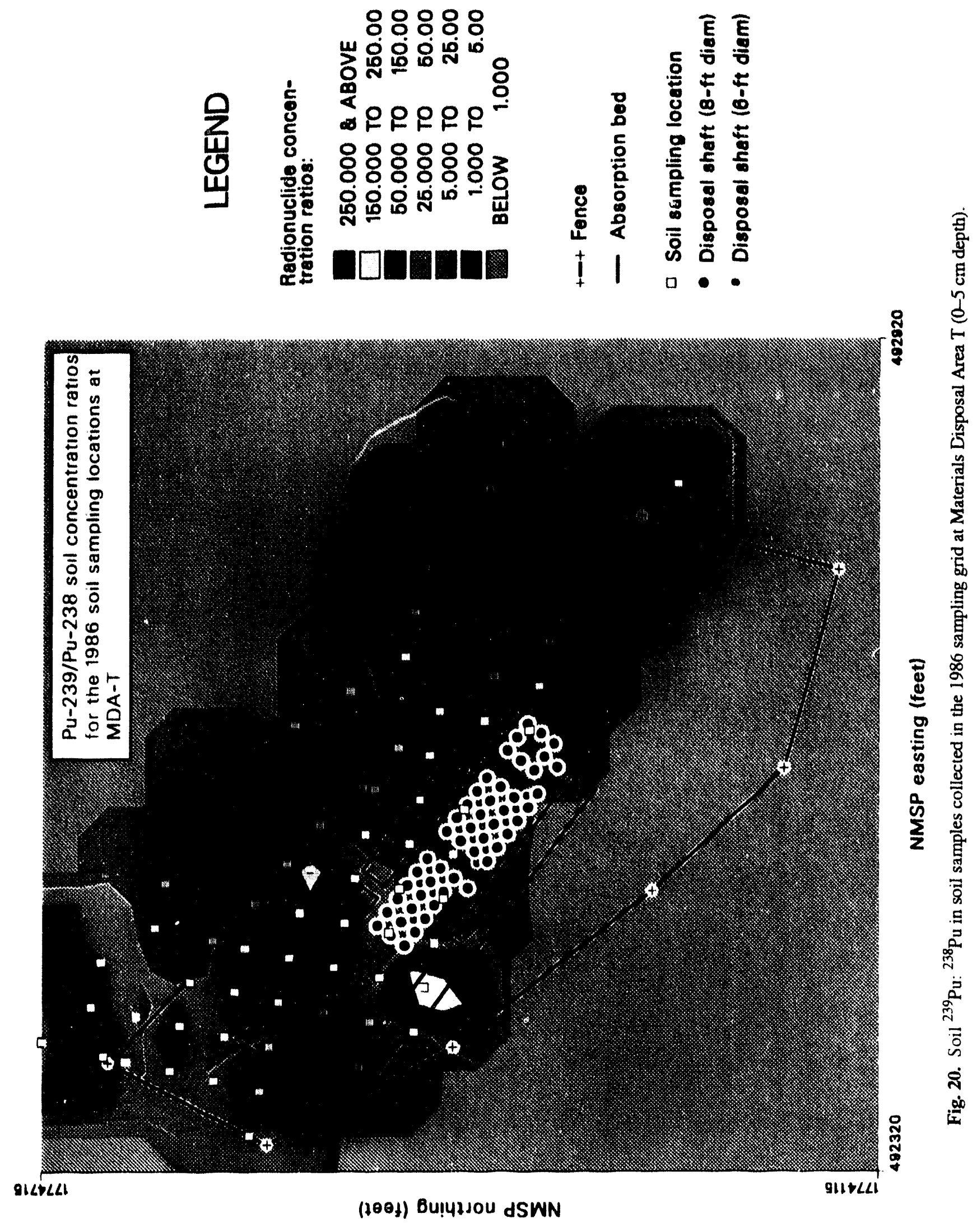




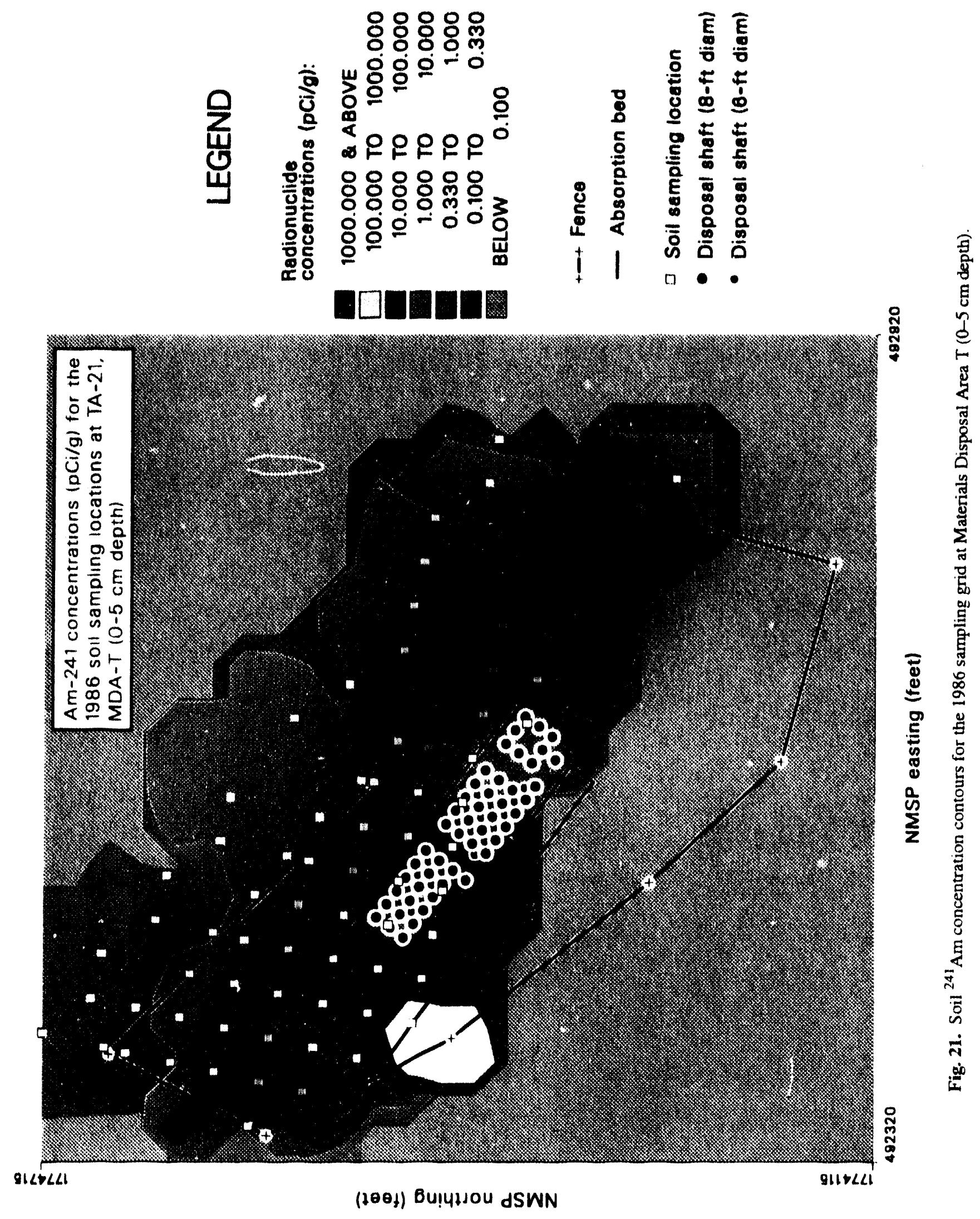


The other area of notice (Fig. 21) is again the land north of the disposal site. The dominant bluegreen-colored contours in this area, corresponding $10{ }^{24} \mathrm{Am}$ concentrations ranging from 1 10 $10 \mathrm{pCi} / \mathrm{g}$, with the upper limit of ${ }^{241} \mathrm{Am}$ background concentrations being $0.33 \mathrm{pCi} / \mathrm{g}$ (dark blue-colored contours). Since this same trend was noticed with the soil plutonium results, similar speculated deposition mechanisms could have occurred for ${ }^{24 !} \mathrm{Am}$.

\section{USEFULAESS OF DATA ANALYSIS AND RECOMMENDATIONS FOR FUTURE STUDIES}

The analysis of the surface soil sumpling programs at MDA.T is potentially very useful to the Environmental Restoration Program, the site operator, the Environmental Surveillance Group, the Laboratory, and the waste management community in general. More specifically, this report serves 10 document two major past attempts to document the distribution of radionuclides at this waste site. There is already an ongoing attempt to design another soil sampling program at this waste disposal site by the Environmental Restoration Program. Although the entire surface of MDA. T received a new soil cover in 1987, the radionuclide concentration contours presented in this report can be used to plan a subsurface soil sampling program based on previous information. The concept in this case would be 10 collect a constant number of samples per unit area within each radionuclide concentration contour. This would result in a much more cost efficient survey, which, based on our comparison of the 1984 and 1986 survey, shouid contain sample locations on (at least) $10 \mathrm{~m}$ centers. The survey results are now in a format which can be used (o) perform a human dose assessment analysis for this waste disposal site, and thus, subsequently make recommendations for site cleanup and remediation.

Several general recommendations can be made from the analysis of the 1984 and 1986 surveys at this waste site:

(1) Although the stated objectives of the original plan 16. monitor this disposal site (4) came close 10 being met III... 1984 and 1986 intensive surveys, an analysis of the results of the brief annual surveys would not be worth performing. The level of effort needed (1) adequately document these surveillance activities is not worth it for the small number of sample data collecled (conseyuently, we also recommend that only detailed surveys should be performed in the future)
(2) Future soil radionuclide surveys should require a high documentation level by civil engineering surveyors and personnel in charge of describing sampling locations (in NMSP units).

(3) Detailed soil radionuclide surveys should be performed for subsurface (below $30 \mathrm{~cm}$ ) regions of this and other, disposal sites.

(4) Analysis of surface soil radionuclide surveys such as performed in the current study should be performed for the other disposal areas at TA.21

(5) Once (3) and (4) have been accomplished, the entire technical area should be analyzed so as 10 put together a comprehensive picture of the impact of local air-horne and water erosion patterns on the mesa lop.

\section{REFERENCES}

1. "DOE: Operating (iuidelines for the Shallow Land Burial of Low-level Radioactive Waste," lici\&(i. Idaho, Interim Draft Number 1 (November 1978).

2. "DOE Site Design Criteria for the Shallow Land Disposal oflow-level Radioactive Waste," ECi\&Ci. Idaho, Drafi Number I (November 1981).

3. "I)evelopment of Moniloring Programs for IRI)A (Owned Radionctive Low-Level Waste Burial Sites," Dames \& Moore, linal report (July 1976).

4. W. K. Hansen, D. I. Maylield, and 1. J. Walker, "Interim Environmentad Surveillance Plan for L.ASL. Radioactive Waste Areas," Report (o) DOE: Al.O. and Management Offices, Los Alamos Scientific Laboratory report L.A.I/R-9)(0-31]1)(()ctober 1980)

5. Environmental Science (iroup, Environmental Surveillance Ciroup, Heallh and linvironmental Chemistry (iroup, and Waste Management Giroup. "Environmental Surveillance of low-level Raddoactive Waste Management Areas al Los Alamos During 1986", Los Alamos National Laboratory report I.A-(IR-87.4121 (December 1987). 
6. M. A. Rogers, "History and Environmentul Setling of LASL Near Surface Land Disposal Facilities for Radioactive Wastes (Areas A, B. C, D, I, I, , i, and T); A Scource Document," Los Alamos Scientific Laboratory report LA- 6848 (Junc 11)77).

7. Anonymous, "Transuranic solid waste management research programs quarterly report. OcloherDecember 1973". Los Alamos Scientific Lah Rep. I.A.5614.PR (1974).

8. M. Burns, Lahoratory Waste Management Ciroup, personal communication, March 9. 1990.

9. K Jacobsen, Laboratory linvironmental Surveil. lance (iroup, personal communication. March 8 . 1990

10. Environmental Survelllance (iroup. Project $\wedge 411$ Records.11. Environmental Survelllance (iroun, "Environmental Survetllance at l.os Alamos During 1980", Los Alamos National Laboratory report 1.A-8810-ENV (April 1981).

12. Environmental Surveillance (iroup, "Envirunmental Surveillance at L.os Alamos during 1986", I.0s Alamos National Laboratory report 1.A-1(1)9)2-1:NV (1987)

13. Environmental Surveillance Ciroup. "Environmental Surveillance at L.os Alamos During 1970," I.os Alamos National Laboratory report L.A-82(0)-ENV (April 1980)

14. Purtymun, W. D., R J, Peters, T I: Buhl, M. N. Maes, and If H Brown, "Background Concentrations of Radionuclides in Soils and River Sediments in Northern New Mexico, 1974.1986". Los Alamos National I, aboratory report I. A.11134. MS (November 1987) 

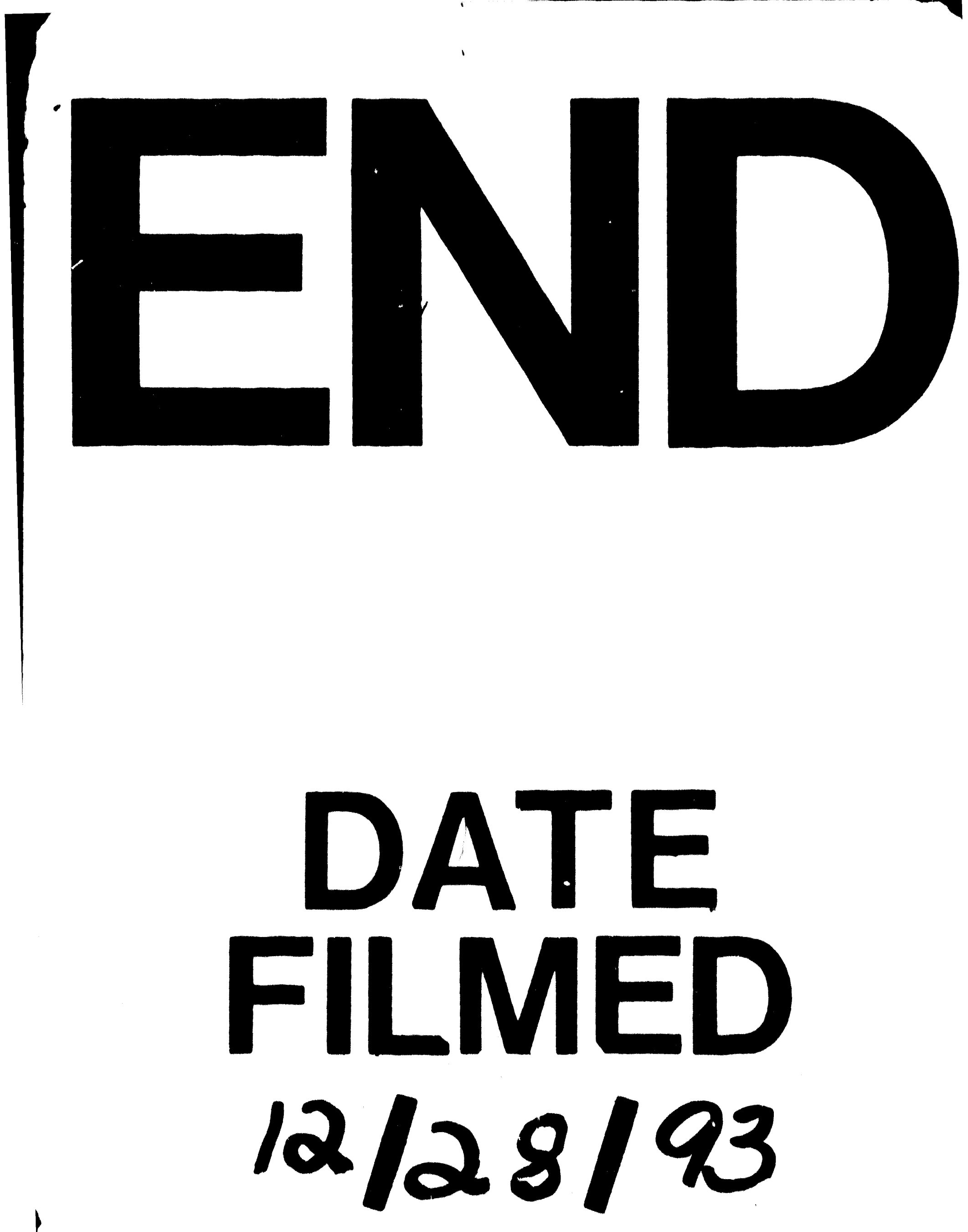

1 

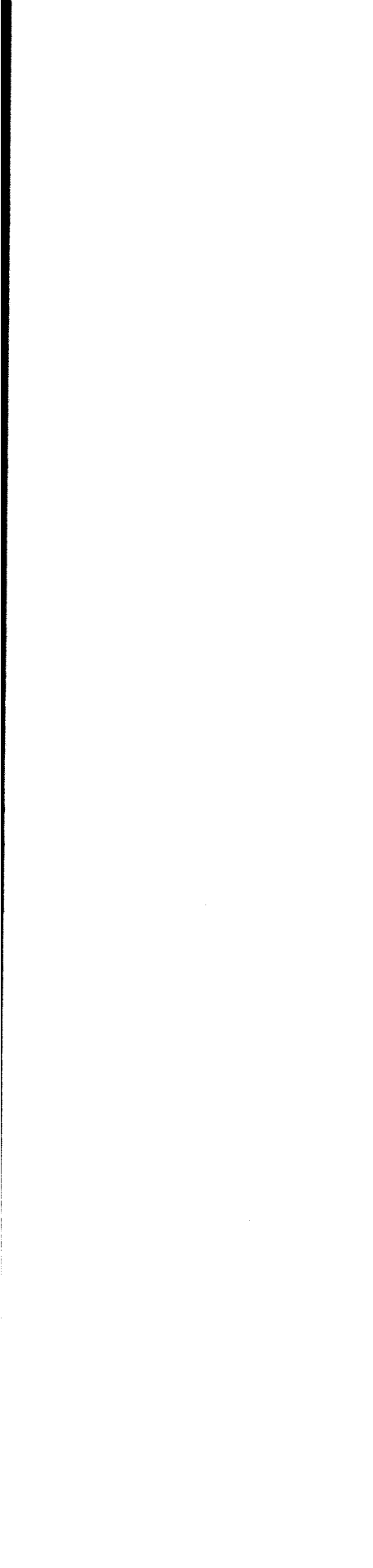